\title{
Global distributions of methanol and formic acid retrieved for the first time from the IASI/MetOp thermal infrared sounder
}

\author{
A. Razavi ${ }^{1}$, F. Karagulian ${ }^{1, *}$, L. Clarisse ${ }^{1, * *}$, D. Hurtmans ${ }^{1}$, P. F. Coheur ${ }^{1, * *}$, C. Clerbaux ${ }^{2,1}$, J. F. Müller ${ }^{3}$, and \\ T. Stavrakou ${ }^{3}$ \\ ${ }^{1}$ Service de Chimie Quantique et Photophysique, Université Libre de Bruxelles (U.L.B.), Brussels, Belgium \\ ${ }^{2}$ UPMC Univ. Paris 06; Université Versailles St-Quentin; CNRS/INSU, LATMOS-IPSL, Paris, France \\ ${ }^{3}$ Belgian Institute for Space Aeronomy (BIRA-IASB), Brussels, Belgium \\ *now at: European Commission, Joint Research Centre (JRC), 21027 Ispra, Italy \\ *** These authors are respectively Postdoctoral Researcher and Research Associate with FRS-FNRS, Belgium
}

Received: 15 July 2010 - Published in Atmos. Chem. Phys. Discuss.: 8 September 2010

Revised: 14 January 2011 - Accepted: 24 January 2011 - Published: 31 January 2011

\begin{abstract}
Methanol $\left(\mathrm{CH}_{3} \mathrm{OH}\right)$ and formic acid $(\mathrm{HCOOH})$ are among the most abundant volatile organic compounds present in the atmosphere. In this work, we derive the global distributions of these two organic species using for the first time the Infrared Atmospheric Sounding Interferometer (IASI) launched onboard the MetOp-A satellite in 2006. This paper describes the method used and provides a first critical analysis of the retrieved products. The retrieval process follows a two-step approach in which global distributions are first obtained on the basis of a simple radiance indexing (transformed into brightness temperatures), and then mapped onto column abundances using suitable conversion factors. For methanol, the factors were calculated using a complete retrieval approach in selected regions. In the case of formic acid, a different approach, which uses a set of forward simulations for representative atmospheres, has been used. In both cases, the main error sources are carefully determined: the average relative error on the column for both species is estimated to be about 50\%, increasing to about $100 \%$ for the least favorable conditions. The distributions for the year 2009 are discussed in terms of seasonality and source identification. Time series comparing methanol, formic acid and carbon monoxide in different regions are also presented.
\end{abstract}

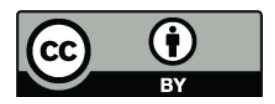

Correspondence to: A. Razavi

(arazavi@ulb.ac.be)

\section{Introduction}

Volatile Organic Compounds (VOCs) includes thousands of different carbon-containing gases present in our atmosphere at concentrations ranging from less than a pptv to more than a ppmv (only methane exceeds $1 \mathrm{ppmv}$ and is usually excluded from the VOC definition). Emitted from a large variety of processes (biogenic or anthropogenic) at the Earth's surface, they have an important influence on the atmospheric composition and climate. VOCs are precursors to tropospheric ozone (Houweling et al., 1998), they play an important role on the oxidizing capacity of the troposphere (Atkinson and Arey, 2003; Monks, 2005), they lead to the formation of secondary organic aerosols (Tsigaridis and Kanakidou, 2007; Heald et al., 2008) and they impact on climate change in different indirect ways (Meinshausen et al., 2006; Feingold et al., 2003; Charlson et al., 1987). In order to better understand and quantify their emissions and the role they play in the Earth's system, it is important to assess their atmospheric distribution at the global scale.

\subsection{Observation of VOCs from space}

The first steps in measuring volatile organic compounds by infrared satellite sounders were made during the last years, mostly using high-sensitive limb-viewing instruments. Methanol and formic acid, along with a series of other compounds, have been observed in young or aged biomass burning plumes with the ACE-FTS instrument (Rinsland et al., 2004; Dufour et al., 2006; Coheur et al., 2007; Rinsland et al., 2007; Herbin et al., 2009). Large datasets of that sounder, covering several years, have been gathered to provide quasiglobal distributions of these two species and to study their seasonal variability (Rinsland et al., 2006; Dufour et al.,

Published by Copernicus Publications on behalf of the European Geosciences Union. 
2007; Abad et al., 2009). Similarly the observations of the MIPAS limb emission sounder have enabled mapping upper tropospheric distributions of several organic species such as PAN (Glatthor et al., 2007; Moore and Remedios, 2010), acetone (Moore et al., 2010) as well as $\mathrm{HCN}$ and $\mathrm{C}_{2} \mathrm{H}_{6}$ (Glatthor et al., 2009); very recently global distributions of formic acid have also been gathered and analyzed (Grutter et al., 2010). The possibility of probing these VOCs lower in the atmosphere using nadir infrared sounders was suggested based on local observations, both by TES (Beer et al., 2008) and IASI (Coheur et al., 2009), in the latter case in large biomass burning plumes.

Other VOC observations from space have been performed using ultraviolet (UV) sounders. The GOME and OMI instruments provide measurements of formaldehyde (Chance et al., 2000; Millet et al., 2008b), providing constraints on the emissions of isoprene (Shim et al., 2005; Palmer et al., 2006) and other non-methane volatile organic compounds (NMVOCs) (Fu et al., 2007; Stavrakou et al., 2009). With the complementary use of SCIAMACHY (De Smedt et al., 2008) and with the GOME follow-on instrument onboard MetOp-A (GOME-2), a long-term dataset (14 years) of formaldehyde observations is now available. In addition, measurements of glyoxal have also been made from the SCIAMACHY instrument (Wittrock et al., 2006; Vrekoussis et al., 2009).

This study provides the first global distributions of methanol and formic acid observed by the IASI (Infrared Atmospheric Sounding Interferometer) instrument (Phulpin et al., 2007), briefly described in Sect. 2.1. This infrared nadir-looking sounder has already demonstrated its potential for the monitoring of different trace gases such as $\mathrm{CO}$ (George et al., 2009; Turquety et al., 2009), $\mathrm{O}_{3}$ (Boynard et al., 2009), $\mathrm{CH}_{4}$ (Razavi et al., 2009) and $\mathrm{HNO}_{3}$ (Wespes et al., 2009). IASI has also demonstrated its high sensitivity to weak absorbers such as $\mathrm{NH}_{3}$, for which global and local distributions have been obtained (Clarisse et al., 2009, 2010). The same method as the one used for retrieving global $\mathrm{NH}_{3}$, and which relies on a simple difference of brightness temperatures, has been adapted to retrieve methanol and formic acid total columns. The method is described in Sect. 2.2 and a critical analysis of the resulting methanol field is provided in Sect. 3. The latter includes a first interpretation of the global distributions and seasonality of methanol as well as an error analysis. Section 4 provides similar analysis for formic acid. In addition, time series comparing the two species and $\mathrm{CO}$ for selected regions are presented in Sect. 5.

Prior to this, a review of sources, sinks and previous measurements of methanol and formic acid is provided.

\subsection{Methanol}

Methanol $\left(\mathrm{CH}_{3} \mathrm{OH}\right)$ is the most abundant organic species in the Earth's atmosphere after methane and is also the main non-methane organic volatile compound in the mid to up- per troposphere (Heikes et al., 2002). Because its main removal process is oxidation by $\mathrm{OH}$ (Atkinson, 1986), $\mathrm{CH}_{3} \mathrm{OH}$ has a noticeable impact on the oxidizing capacity of the troposphere and on the global budget of tropospheric ozone (Tie et al., 2003). Additional sinks include removal by dry and wet deposition and uptake by the ocean (Jacob et al., 2005; Millet et al., 2008a). Its mean lifetime is evaluated to be about 10 days in the free troposphere. The main emission sources of methanol are biogenic processes, involving plant growth (MacDonald and Fall, 1993; Nemecek-Marshall et al., 1995; Harley et al., 2007; Galbally and Kirstine, 2002) and plant decay to a lesser extent (Warneke et al., 1999). Other sources include biomass burning (Holzinger et al., 2005), oxidation of methane and other VOCs, as well as anthropogenic emissions from vehicles and industrial activities (Singh et al., 2000). There still exists large uncertainties in the relative source strengths, the atmospheric distribution and budget of $\mathrm{CH}_{3} \mathrm{OH}$ (Singh et al., 2000; Tie et al., 2003; Jacob et al., 2005).

During the past few years, coordinated measurement campaigns have been conducted which provide, among other trace species, in situ and aircraft determination of methanol abundances, and from there information about its different emission sources. The diurnal and seasonal cycle of $\mathrm{CH}_{3} \mathrm{OH}$ has been studied from in situ measurement in different types of environments such as forest (Karl et al., 2003, 2005), rural (Schade and Goldstein, 2006; Brunner et al., 2007; Jordan et al., 2009) or urban areas (Filella and Peņuelas, 2006; Nguyen et al., 2001) with a variety of techniques. The concentrations usually increase during daytime due to the light induced release of methanol by plants. Moreover, $\mathrm{CH}_{3} \mathrm{OH}$ abundances are found to be higher during spring because of high plant growth emissions during that season. Methanol concentrations of about $4 \mathrm{ppbv}$ have been reported in the amazonian region (Karl et al., 2007; Eerdekens et al., 2009). Aircraft measurements were also carried out over oceans (Singh et al., 2000, 2004) where background concentrations of a few hundreds of pptv were found. Airborne observations led also to the study of $\mathrm{CH}_{3} \mathrm{OH}$ in several biomass burning plumes (Yokelson et al., 1999; Fischer et al., 2003; Yokelson et al., 2003; Holzinger et al., 2005) where volume mixing ratios (vmr) of up to several tens of ppbv were found. Observations of $\mathrm{CH}_{3} \mathrm{OH}$ with ground-based infrared spectrometers were also recently conducted in Australia (Paton-Walsh et al., 2008) and in Arizona (Rinsland et al., 2009). The latter study provides an unprecedented 22 years time series of free tropospheric $\mathrm{CH}_{3} \mathrm{OH}$; it does not report any significant trend over the years but shows a clear seasonality with a maximum in early July and a minimum during January.

The quasi-global distributions obtained from ACE-FTS (Dufour et al., 2007) have further revealed that the surface sources of methanol have a significant impact on its upper tropospheric concentrations, which are mostly driven by biogenic and biomass burning emissions in the Northern and Southern Hemisphere, respectively. Beer et al. (2008) 
has firstly demonstrated the possibility to measure methanol from a nadir infrared sounder and reports lower $\mathrm{CH}_{3} \mathrm{OH}$ concentrations in California than near Beijing, where emissions could be caused by local sources.

The strongest absorption band of methanol in the infrared is the $v_{8}$ CO-stretching mode centered at $1033 \mathrm{~cm}^{-1}$. We have used line parameters of Xu et al. (2004), implemented in the HITRAN database for which a precision of $6 \%$ for line intensities is quoted.

\subsection{Formic acid}

Formic acid ( $\mathrm{HCOOH})$ is one of the most abundant organic acid and has a strong influence on pH-dependent chemical reactions in clouds (Keene and Galloway, 1988). It has also been identified as a major sink for $\mathrm{OH}$ reactions in cloud water (Jacob, 1986). Although its sources and sinks are still poorly quantified, $\mathrm{HCOOH}$ is known to be emitted by various processes: biomass burning (Goode et al., 2000; Worden et al., 1997; Yokelson et al., 1997), biogenic emissions from vegetation (Keene and Galloway, 1984, 1988), emissions from soil (Sanhueza and Andreae, 1991), from ants (Graedel and Eisner, 1988), as a secondary product from organic precursors (Rasmussen and Khalil, 1988; Arlander et al., 1990) and also from motor vehicles (Kawamura et al., 1985; Grosjean, 1989). Formic acid can be also produced from the aqueous oxidation of formaldehyde in cloud and rain water (Chameides and Davis, 1983) as well as from the oxidation of formaldehyde by $\mathrm{HO}_{2}$ radicals in the cold tropopause region (Hermans et al., 2005). It is mainly removed from the troposphere through wet and dry deposition but also through oxidation by the $\mathrm{OH}$ radical to a lesser extent. The resulting lifetime of $\mathrm{HCOOH}$, estimated to be a few days in the boundary layer, increases in the free troposphere because of the scarcity of precipitation (Sanhueza et al., 1996). HCOOH has been found to be a product of the isoprene oxidation by ozone (Jacob and Wofsy, 1988; Martin et al., 1991) and by $\mathrm{OH}$ radicals, in particular through the OH-oxidation of glycolaldehyde (Butkovskaya et al., 2006a) and hydroxyacetone (Butkovskaya et al., 2006b), which are two important isoprene oxidation products, but also through the $\mathrm{OH}$-oxidation of isoprene nitrates (Paulot et al., 2009).

In situ measurements of formic acid in the boundary layer have been carried out using different techniques in various parts of the world, from rural sites (Talbot et al., 1988; Puxbaum et al., 1988; Talbot et al., 1990; Hartmann et al., 1991; Helas et al., 1992) to urban areas (Grosjean, 1989; Khwaja, 1995; Granby et al., 1997; Souza et al., 1999). The observed $\mathrm{HCOOH}$ volume mixing ratio in the boundary layer ranges from 0.01 to $10 \mathrm{ppbv}$. Its diurnal cycle shows larger concentrations in the mid- to late afternoon (Martin et al., 1991; Hartmann et al., 1991) indicating larger sources during daytime (biogenic emission, photochemical reactions) and dry deposition at nighttime.
$\mathrm{HCOOH}$ measurements in the upper troposphere, performed during several aircraft campaigns (Reiner et al., 1999; Jaeglé et al., 2000; Singh et al., 2000), have reported mixing ratios from about 30 to $215 \mathrm{pptv}$. $\mathrm{HCOOH}$ has also been probed in different biomass burning plumes (Yokelson et al., 1999; Goode et al., 2000; Herndon et al., 2007) with concentrations of around ten ppbv; Worden et al. (1997) reported $\mathrm{HCOOH}$ total columns of 8.6 and $11.2 \times$ $10^{16}$ molec $\mathrm{cm}^{-2}$ above two fire events in the USA using optical measurements in the infrared. Similar spectral measurements, which used the $\mathrm{HCOOH} v_{6}$ absorption band in the IR, were performed from a balloon (Goldman et al., 1984; Remedios et al., 2007), with mixing ratios up to $600 \mathrm{pptv}$ at about $7 \mathrm{~km}$ height, or from the ground (Rinsland et al., 2004). The latter study gives insight on the seasonal variation of $\mathrm{HCOOH}$, with a mean mixing ratio in the free troposphere from about $300 \mathrm{pptv}$ in October-December to about 800 pptv in July-September, likely resulting from higher biogenic emissions during the growing season. Other groundbased measurements above Jungfraujoch were very recently analyzed over a 22 years period and show a similar seasonal cycle with a maximum occurring during summer as well as significant diurnal and day-to-day variability (Zander et al., 2010).

The first satellite observations in the upper troposphere were reported from the ACE-FTS instrument (Rinsland et al., 2006, 2007; Coheur et al., 2007) and were correlated to biomass burning events. Recent work performed with ACEFTS on quasi-global observations of $\mathrm{HCOOH}$ reported an average mixing ratio of about $0.3 \mathrm{ppbv}$ in the free troposphere with hot spots of up to $0.59 \mathrm{ppbv}$ in tropical regions (Abad et al., 2009). Very recent global distributions were also assessed by the MIPAS sounder (Grutter et al., 2010) over a 6 years period. They report seasonal variations that may be associated to biogenic emissions with higher mixing ratios at $8 \mathrm{~km}$ during summer (about $100 \mathrm{pptv}$ ) than in winter (about 45 pptv). High concentrations were also observed in biomass burning plumes in the Southern Hemisphere. The nadir-viewing IASI sounder has also recently demonstrated the possibility to observe the $\mathrm{HCOOH}$ spectral signature in fire plumes (Coheur et al., 2009). In this study, we provide the first distributions of formic acid total columns above land, differentiated into four seasons for the year 2009. The retrieval method is slightly different from the one used for methanol because the conversion factor between brightness temperature differences and total columns is derived from a set of forward simulation. Details and error estimation are provided in Sect. 4.1.

We have used a new set of $\mathrm{HCOOH}$ spectroscopic line parameters of Vander Auwera et al. (2007), implemented in the latest versions of HITRAN and GEISA databases. The accuracy on the absolute line intensities is evaluated to be about $7 \%$. The updated data set reports $\mathrm{HCOOH}$ line intensities larger by about a factor 2 compared to previous studies (Perrin and Vander Auwera, 2007). This implies that 
concentrations obtained from infrared retrievals before 2007 were likely too high by the same factor.

\section{Instrument and method}

\subsection{Description of IASI}

The IASI instrument, launched onboard the MetOp-A platform in October 2006 in a polar sun-synchronous orbit, is a nadir-looking Fourier transform spectrometer that records the Earth's outgoing radiation from 645 to $2760 \mathrm{~cm}^{-1}$ without gaps at an apodized resolution of $0.5 \mathrm{~cm}^{-1}$. Its field of view is a $2 \times 2$ matrix of circular pixels which have a $12 \mathrm{~km}$ footprint diameter at nadir. IASI provides two global Earth coverages per day (about 1280000 spectra) thanks to the wide scans across its track ( $2200 \mathrm{~km}$ swaths). It offers also a very good signal-to-noise ratio, with a Noise Equivalent Delta Temperature (NEDT) at $280 \mathrm{~K}$ of about $0.2 \mathrm{~K}$ in the spectral region of interest (which extends from 975 to $1150 \mathrm{~cm}^{-1}$ ). Moreover, with the successive launch of two other identical instruments, the IASI mission will provide consistent measurements over a 15 years period. A technical description of IASI and examples of applications for chemistry can be found in the review of Clerbaux et al. (2009). The IASI calibrated radiance spectra are disseminated in nearreal time by the EumetCast system along with temperature, humidity profiles and cloud information (coverage, temperature and altitude). Only cloud free observations (when the cloud coverage for the pixel is below $2 \%$ ) are taken into account for this study.

The measurement of methanol and formic acid concentrations from IASI is quite challenging due to their weak absorption and the interference of other molecules in the same spectral range (see Fig. 1). $\mathrm{CH}_{3} \mathrm{OH}$ is observable using its $\mathrm{C}-\mathrm{O}$ stretching absorption band located around $1033 \mathrm{~cm}^{-1}$. The spectral range also covers the $v_{6}$ absorption band of $\mathrm{HCOOH}$ located near $1105 \mathrm{~cm}^{-1}$ and the $\nu_{3}$ band of trans- $\mathrm{HCOOH}$ at $1777 \mathrm{~cm}^{-1}$ (Perrin et al., 2009), which cannot be detected in the IASI spectra because of strong water vapor interferences.

\subsection{Retrieval approach}

In order to take advantage of the very good spatial coverage of IASI we have chosen a simple, fast and robust approach based on brightness temperature differences $\left(\Delta T_{\mathrm{b}}\right)$, similar to the method already used for the retrieval of sulfur dioxide (Clarisse et al., 2008) and ammonia (Clarisse et al., 2009). It consists in two steps: (i) the determination of $\Delta T_{\mathrm{b}}$ globally and (ii) the conversion of $\Delta T_{\mathrm{b}}$ to total column amounts using one (global) or two (continental and oceanic) conversion factors.

The $\Delta T_{\mathrm{b}}$ corresponds to the difference between the brightness temperatures measured in one or several channels selected in the absorption signature of the target molecule
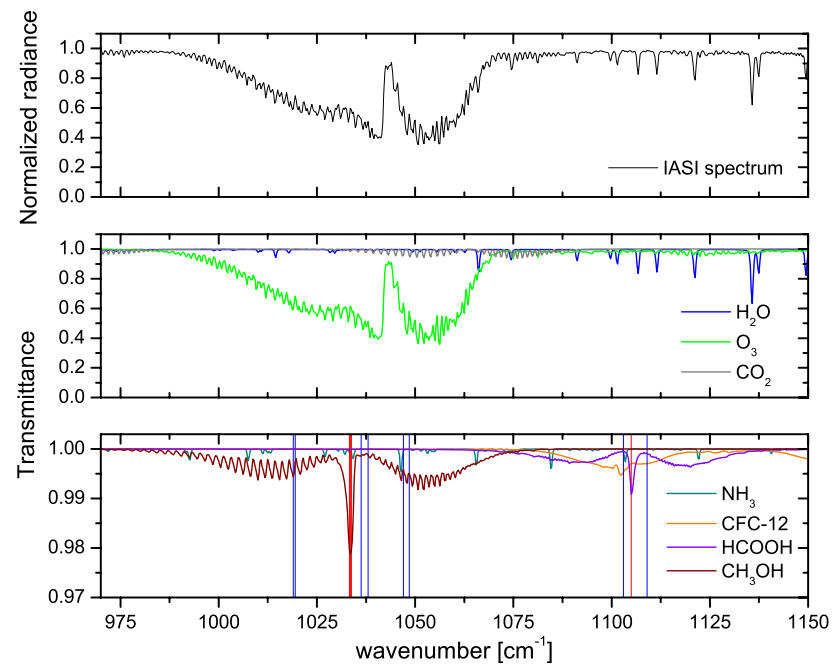

Fig. 1. Top panel: IASI normalized radiance spectrum in the spectral region between 950 and $1200 \mathrm{~cm}^{-1}$ containing methanol and formic acid absorption bands. Bottom panels: Contribution to the IASI spectrum of different atmospheric species plotted in transmittance. The vertical lines indicate the target channels (in red) and the baseline channels (in blue) which are used for the $\Delta T_{\mathrm{b}}$ determination (nine channels are used for $\mathrm{CH}_{3} \mathrm{OH}$, and three for $\mathrm{HCOOH}$ ). See Sect. 2.2 for details.

$\left(T_{\mathrm{b}, \text { target }}\right)$ and the brightness temperature of nearby channels selected in a spectral region where the least absorptions are found $\left(T_{\mathrm{b}, 0}\right)$. This is expressed in the following equation as

$\Delta T_{\mathrm{b}}=\left\langle T_{\mathrm{b}, 0}\right\rangle-\left\langle T_{\mathrm{b}, \text { target }}\right\rangle$

This quantity gives a handy estimate for the strength of absorption and hence of the concentration. However, the physics of the radiative transfer is not accounted for and the conversion of $\Delta T_{\mathrm{b}}$ to total columns requires a full radiative transfer treatment. For this purpose, we have retrieved $\mathrm{CH}_{3} \mathrm{OH}$ total columns at various locations of the world with an inversion model based on the Optimal Estimation Method (OEM) (Rodgers, 2000) that includes a line-by-line radiative transfer model. This is implemented in the Atmosphit software developed at the Université Libre de Bruxelles (for more information see Clarisse et al., 2008 and Coheur et al., 2005). The method is only applied in selected regions due to computational limitations. The conversion factor derived by matching the retrieved columns on the corresponding $\Delta T_{\mathrm{b}}$ is applied globally to derive the total column distributions.

For $\mathrm{HCOOH}$, we used an alternative conversion method only based on forward simulations (see Sect. 4.1).

In the next two sections we describe the different retrieval parameters (the chosen channels, spectral intervals and a priori information) and present the resulting global distributions for $\mathrm{CH}_{3} \mathrm{OH}$ and $\mathrm{HCOOH}$, respectively. 


\section{Methanol retrieval and distributions}

\subsection{Retrieval settings}

Methanol a priori profiles and covariance matrices were derived from distributions calculated by the IMAGESv2 global chemistry-transport model (Stavrakou et al., 2009). Monthly averaged model profiles over the whole year 2007 were used globally, on a $4^{\circ} \times 5^{\circ}$ latitude-longitude grid to account for the seasonal and spatial variability of the model. Two different vertical profiles were selected: an average continental and an average oceanic profile. This choice is justified by the existence of strong emission over continents resulting in enhanced concentrations in the boundary layer. These two profiles are illustrated on Fig. 2 together with their associated covariance matrix (where the diagonal elements represent the model variability for the profile, and the off-diagonal elements represent the correlation between values at different altitudes). The continental a priori profile has a surface mixing ratio of about $2.5 \mathrm{ppbv}$, about four times larger than in the oceanic profile. Above $4 \mathrm{~km}$, the two profiles are similar with only slightly higher concentrations for the continental profile. The covariance matrices both show higher variabilities in the lower ( 0 to $2 \mathrm{~km}$ ) and upper (14 to $18 \mathrm{~km}$ ) troposphere. Over continental surfaces, the variabilities are larger by about $25 \%$. In both cases, the correlation length is large.

As can be seen from Fig. 1, the methanol spectral signature is fully overlapped by the much stronger ozone band at $10 \mu \mathrm{m}$. A large spectral range is therefore needed in order to properly account for this strong interference in the retrieval process. The spectral range extending from 981.25 to $1038 \mathrm{~cm}^{-1}$ was selected after several tests. $\mathrm{CH}_{3} \mathrm{OH}$ partial columns are retrieved in $4 \mathrm{~km}$ thick layers from the ground to $16 \mathrm{~km}$. Partial columns of $\mathrm{O}_{3}$ in 6 layers up to $42 \mathrm{~km}$ and the total columns of $\mathrm{H}_{2} \mathrm{O}$ and $\mathrm{NH}_{3}$ are simultaneously adjusted. The regions selected for the retrievals are described in Table 1. These regions/periods were selected because of their high $\Delta T_{\mathrm{b}}$ values and no significant seasonal differences have been noticed. An example of inversion is presented on Fig. 3 (top panel) for a case where the $\mathrm{CH}_{3} \mathrm{OH}$ signature is unambiguous. The RMS of the residue when $\mathrm{CH}_{3} \mathrm{OH}$ is not included in the retrieval is significantly higher $\left(3.1 \times 10^{-6} \mathrm{~W} /\left(\mathrm{m}^{2} \mathrm{sr} \mathrm{m}^{-1}\right)\right)$ than when it is taken into account $\left(2.5 \times 10^{-6} \mathrm{~W} /\left(\mathrm{m}^{2} \mathrm{sr} \mathrm{m}^{-1}\right)\right)$, this value being very close to the theoretical noise. This specific retrieval leads to a methanol total column of $5.57 \times 10^{16}$ molec $\mathrm{cm}^{-2}$. Retrieved methanol mixing ratios in the lowermost atmospheric layer ( 0 to $4 \mathrm{~km}$ ) range from about 0.1 to $7.0 \mathrm{ppb}$ for the different selected regions. Comparisons between model data optimized with the IASI methanol product and previous $\mathrm{CH}_{3} \mathrm{OH}$ measurements (in situ and aircraft) were carried out and are detailed in the latest work by Stavrakou et al. (submitted to ACP). On the bottom panel of Fig. 3, representative total column averaging kernels differentiated for continental and oceanic retrievals are illustrated. They correspond to
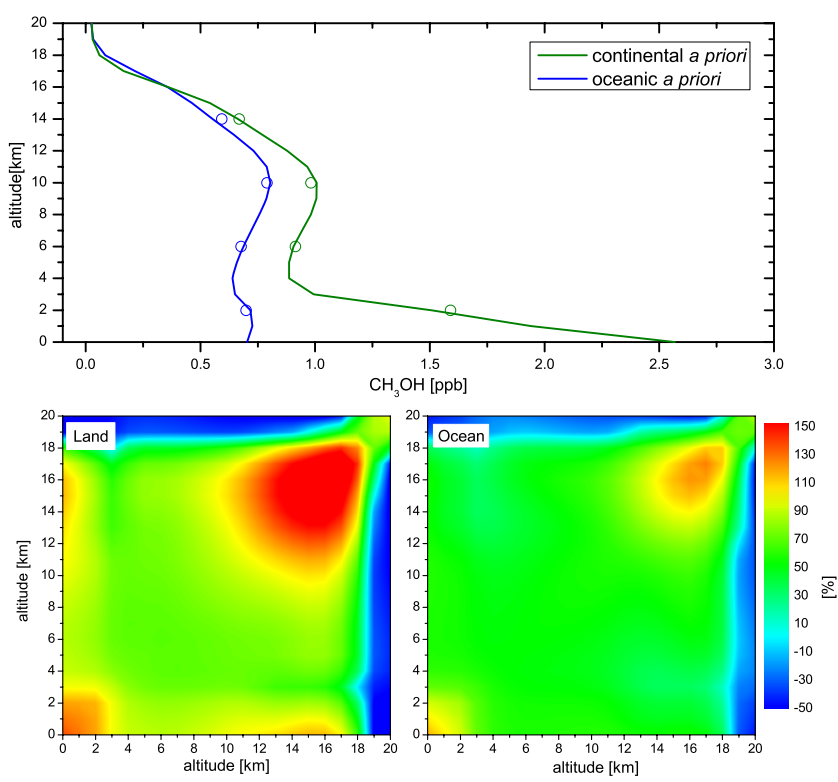

Fig. 2. Top panel: Illustration of the two $\mathrm{CH}_{3} \mathrm{OH}$ a priori profiles (continental and oceanic) derived from the IMAGESv2 CTM model for the year 2007. Open circles represent the a priori on the 4 layers retrieval grid. Bottom panels: Plot (expressed in \%) of the associated covariance matrices (left: for land, right: for ocean).

Table 1. Selected regions and periods for the retrieval of methanol using the Optimal Estimation Method.

\begin{tabular}{llll}
\hline Localization & Region & Date & DOFS range \\
\hline Congo & $0-35^{\circ} \mathrm{S}$ & 20 October 2008 & $0.29-1.02$ \\
& $10-50^{\circ} \mathrm{E}$ & & \\
Chad & $0-25^{\circ} \mathrm{N}$ & 5 April2009 & $0.77-1.05$ \\
& $0-30^{\circ} \mathrm{E}$ & & \\
Brazil & $0-20^{\circ} \mathrm{S}$ & 20 October 2008 & $0.45-1.02$ \\
& $35-60^{\circ} \mathrm{W}$ & & \\
India & $5-40^{\circ} \mathrm{S}$ & 2 May 2009 & $0.50-1.06$ \\
& $70-90^{\circ} \mathrm{E}$ & & \\
\hline Atlantic & $30^{\circ} \mathrm{S}-25^{\circ} \mathrm{N}$ & 11 August 2008 & $0.12-0.87$ \\
& $10-40^{\circ} \mathrm{W}$ & & \\
& & &
\end{tabular}

the mean averaging kernels for all retrievals performed in the selected regions. In both cases, the sensitivity is maximum in the mid to upper troposphere from about 5 to $11 \mathrm{~km}$, but retrievals over land show much higher sensitivity near the ground, largely due to the higher thermal contrast (Clerbaux et al., 2009). The resulting DOFS (Degrees Of Freedom for Signal, given by the trace of the averaging kernel matrix) for these retrievals are given in Table 1. DOFS values range from 0.29 to 1.06 over land and are found lower above the ocean (between 0.12 and 0.87 ) where the dependence on the a priori is therefore larger. 

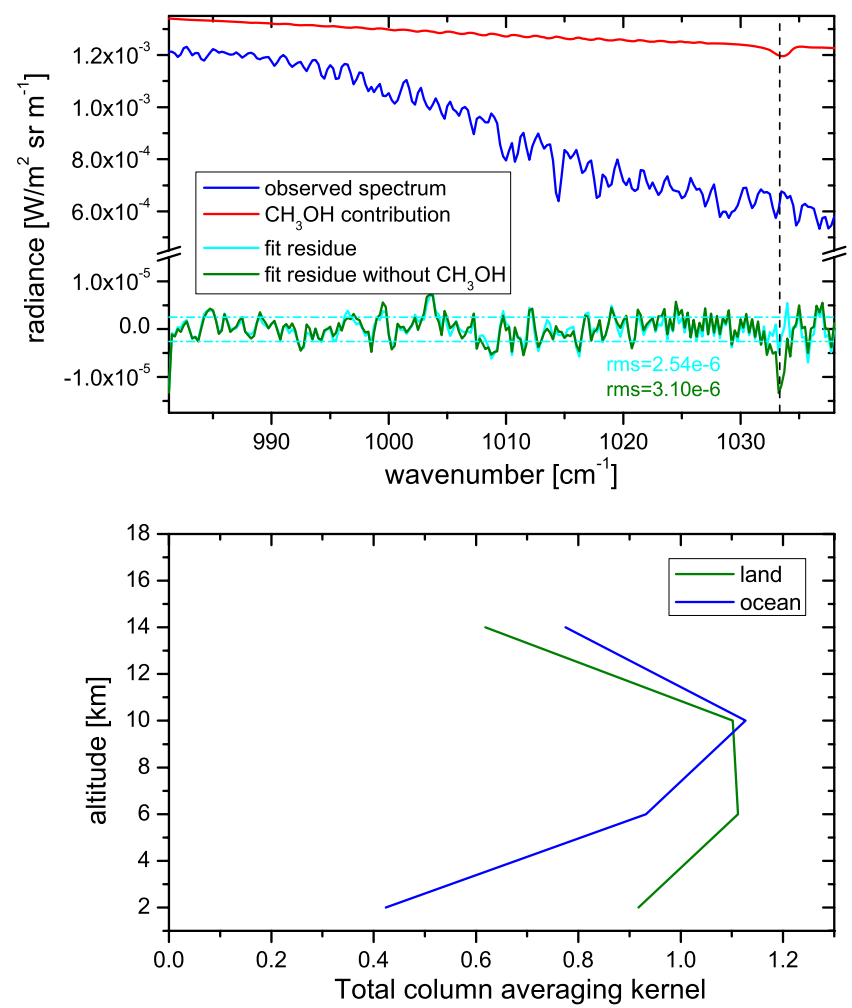

Fig. 3. Top panel: Example of a methanol retrieval from an IASI spectrum recorded over Namibia $\left(20.16^{\circ} \mathrm{S}-21.50^{\circ} \mathrm{E}\right)$ on 20 October 2008. The observed (blue curve) spectrum is shown together with the fit residue (in cyan) and the dashed horizontal lines delimit this residue by its RMS value. The dark green curve is the fit residue when $\mathrm{CH}_{3} \mathrm{OH}$ is not taken into account in the retrieval, the red curve represents the calculated $\mathrm{CH}_{3} \mathrm{OH}$ contribution to the spectrum and the dashed vertical line indicates the detectable $\mathrm{CH}_{3} \mathrm{OH}$ absorption band. Bottom panel: Mean total column averaging kernels presented for retrievals performed over land (green curve) and over ocean (blue curve).

For the global $\Delta T_{\mathrm{b}}$ calculation, the three target channels, all chosen in the Q-branch of $\mathrm{CH}_{3} \mathrm{OH}$ (at 1033.25, 1033.5 and $1033.75 \mathrm{~cm}^{-1}$, see Fig. 1), are also contaminated by $\mathrm{O}_{3}$. Therefore, the baseline channels were also chosen inside the $\mathrm{O}_{3}$ absorption band (at 1019, 1019.5, 1036.25, 1038, 1047 and $1048.5 \mathrm{~cm}^{-1}$, see Fig. 1) in a way that maximizes the sensitivity of $\Delta T_{\mathrm{b}}$ to the $\mathrm{CH}_{3} \mathrm{OH}$ amount. To deal with the remaining contribution of $\mathrm{O}_{3}$, the relationship between $\Delta T_{\mathrm{b}}$ and $\mathrm{O}_{3}$ concentrations has been derived using a set of forward simulations. For different columns of $\mathrm{O}_{3}$ (ranging from 185 to $407 \mathrm{DU}$ ), the spectrum and $\Delta T_{\mathrm{b}}$ were calculated with a fixed amount of $\mathrm{CH}_{3} \mathrm{OH}\left(4 \times 10^{16}\right.$ molec $\left.\mathrm{cm}^{-2}\right)$. The results, presented on Fig. 4 assuming a typical midlatitude summer atmosphere (1976 US standard model), show an approximately linear correlation between the total column of ozone and the calculated $\Delta T_{\mathrm{b}}$. Similar results were obtained for other typical atmospheres and an average linear dependence was computed (with a slope of $9.02 \times 10^{-4} \mathrm{~K} \mathrm{DU}^{-1}$ ).

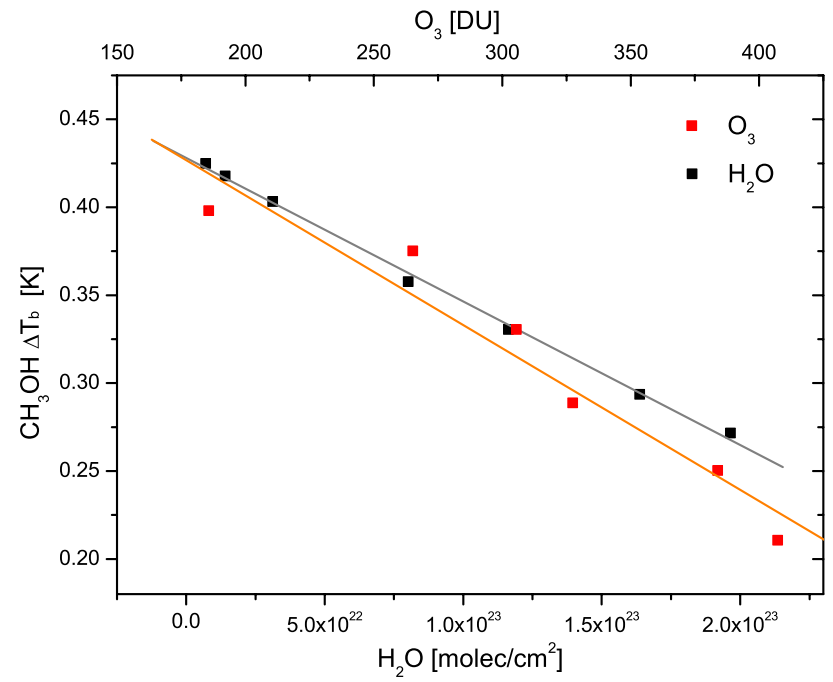

Fig. 4. Illustration of the influence of water vapor and ozone concentrations on the methanol $\Delta T_{\mathrm{b}}$. Simulations were performed for the midlatitude summer model with varying concentrations of $\mathrm{H}_{2} \mathrm{O}$ (black squares) and $\mathrm{O}_{3}$ (red squares) while the $\mathrm{CH}_{3} \mathrm{OH}$ amount was fixed. In both cases, a linear dependence is found.

The $\mathrm{O}_{3}$ correction is assumed here to be altitude independent although our analysis indicates a slightly different behavior for ozone variations in the first kilometers near the surface. For very low $\mathrm{O}_{3}$ concentrations, it is possible that the linear assumption introduces errors in the retrieved methanol columns. However, as concentrations below $200 \mathrm{DU}$ for ozone only occur during the antarctic ozone hole period, this will not affect the distribution discussed here.

The same type of simulations were performed to derive the influence of water vapor on the $\mathrm{CH}_{3} \mathrm{OH} \Delta T_{\mathrm{b}}$ (gray curve in Fig. 4). From these relationships a corrected $\Delta T_{\mathrm{b}}$ for methanol which minimizes the dependence on $\mathrm{O}_{3}$ and $\mathrm{H}_{2} \mathrm{O}$ is calculated as follows

$\Delta T_{\mathrm{b}}^{\prime}=\Delta T_{\mathrm{b}}+9.02 \times 10^{-4} C_{\mathrm{O}_{3}}+8.13 \times 10^{-25} C_{\mathrm{H}_{2} \mathrm{O}}$

where $C_{\mathrm{O}_{3}}$ and $C_{\mathrm{H}_{2} \mathrm{O}}$ are the total columns of $\mathrm{O}_{3}$ in Dobson unit and of $\mathrm{H}_{2} \mathrm{O}$ expressed in molec $\mathrm{cm}^{-2}$, respectively. This correction is applied to all observations using the total columns of $\mathrm{O}_{3}$ and $\mathrm{H}_{2} \mathrm{O}$ retrieved from IASI with a near-real time algorithm based on the OEM.

The next step of the method, i.e. the determination of a suitable conversion factor between $\Delta T_{\mathrm{b}}^{\prime}$ and $\mathrm{CH}_{3} \mathrm{OH}$ total columns, is performed based on the retrievals in the selected regions and dates described in Table 1. Only retrievals results with a DOFS higher than 0.75 and a RMS of the residual lower than $4 \times 10^{-6} \mathrm{~W} /\left(\mathrm{m}^{2} \mathrm{sr} \mathrm{m}^{-1}\right)$ are taken into account. This translates to a total of 5147 and 2849 observations above land and oceans, respectively. The corresponding scatter plots are shown in Fig. 5. In both cases, a linear fit shows good correlation coefficient (about 0.75 ). The slope for the retrievals over land is found to be much larger than 


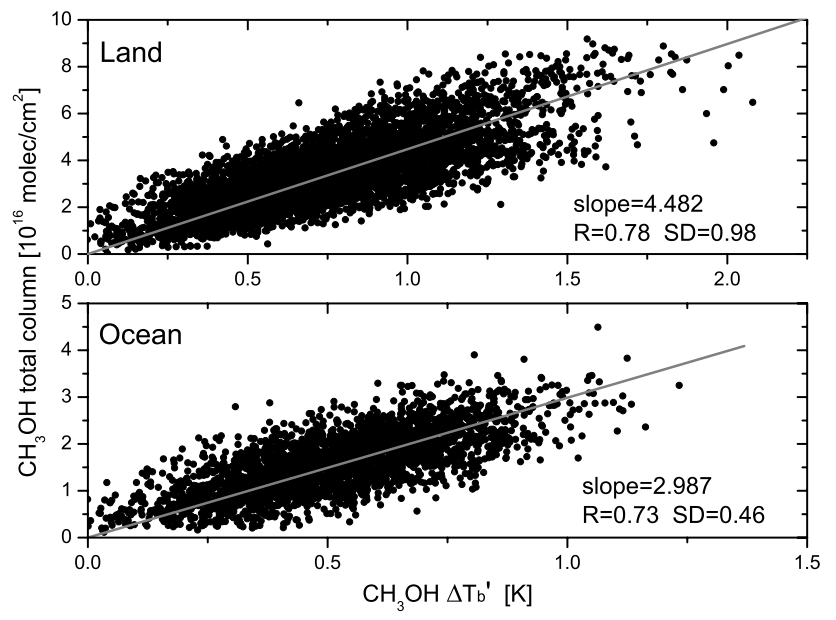

Fig. 5. Correlation between the retrieved total columns of methanol and the corresponding $\Delta T_{\mathrm{b}}$ for various regions (corrected for $\mathrm{O}_{3}$ and $\mathrm{H}_{2} \mathrm{O}$ dependency, see text for details). The conversion factors are given by the slopes of the linear fit (gray curve) separated for retrievals above land (Top panel) and above ocean (Bottom panel). More details about the selected regions for the retrievals can be found in Table 1.

over oceans. Two different conversion factors are therefore used and applied to the $\Delta T_{\mathrm{b}}^{\prime}$ calculated globally:

$$
\begin{aligned}
& C_{\mathrm{CH}_{3} \mathrm{OH}}^{\mathrm{land}}=4.482 \times \Delta T_{\mathrm{b}}^{\prime} \\
& C_{\mathrm{CH}_{3} \mathrm{OH}}^{\mathrm{ocean}}=2.987 \times \Delta T_{\mathrm{b}}^{\prime}
\end{aligned}
$$

where the $\mathrm{CH}_{3} \mathrm{OH}$ total columns $\left(\mathrm{C}_{\mathrm{CH}_{3} \mathrm{OH}}\right)$ are expressed in $10^{16} \mathrm{molec}^{-2}$. Due to its noise, the minimum methanol total column which can be detected by IASI has been evaluated from simulations using the 1976 US standard atmosphere to be about $1.60 \times 10^{16}$ molec $\mathrm{cm}^{-2}$. It is important to note that for the derivation of the global distributions, only cloud free measurements recorded during daytime were taken into account. This is justified because daytime measurements are generally characterized by a positive thermal contrast and are therefore more sensitive to the lower troposphere.

\subsection{Global distributions}

The method proposed above allows to derive the first global distributions of methanol from IASI. In order to shed light onto seasonal variations, the four seasons have been differentiated as follows: DJF (December 2008, January 2009 and February 2009), MAM (March, April and May), JJA (June, July and August) and SON (September, October and November). The resulting distributions averaged on a $0.5^{\circ} \times 0.5^{\circ}$ grid are shown in Fig. 6. Note that measurements above sand surfaces, which causes erroneous high $\mathrm{CH}_{3} \mathrm{OH}$ concentrations due to spectrally resolved surface emissivity (Wilber et al., 1999) have also been discarded.
Figure 6 shows large seasonal variations in the methanol columns. Higher concentrations are found in the northern hemisphere during spring and summer (up to $4 \times$ $10^{16}$ molec $\mathrm{cm}^{-2}$ in Central and Northern Asia) when vegetation is growing. In the Southern Hemisphere, the highest concentrations are found during the dry season ( $\mathrm{SON}$ ) and may be related to biomass burning. $\mathrm{CH}_{3} \mathrm{OH}$ is also observed over oceans (with values around $2 \times 10^{16}$ molec $\mathrm{cm}^{-2}$ ) mostly between Africa and South America but also in the whole Northern hemisphere in spring and summertime. The presence of $\mathrm{CH}_{3} \mathrm{OH}$ in remote oceanic regions is probably largely due to transport of continental emissions although oceanic emissions (Millet et al., 2008a) and the ubiquitous methane oxidation might also contribute. Methanol total columns range from about $0.01 \times 10^{16} \mathrm{molec}^{-2}$ above sea surfaces to $5.40 \times 10^{16}$ molec $\mathrm{cm}^{-2}$ over large emission regions.

During the northern hemispheric winter (DJF), methanol hot spots of low intensity are found in the Southern Hemisphere (South America, South Africa and Western Australia) above vegetated areas where $\mathrm{CH}_{3} \mathrm{OH}$ emissions may be related to plant growth. When comparing the distribution with AATSR (Arino et al., 2005) fire count maps, we find a high degree of coincidence in Africa between 5 and $15^{\circ} \mathrm{N}$, suggesting a possible biomass burning contribution. During springtime (MAM), this specific region is subject to enhanced $\mathrm{CH}_{3} \mathrm{OH}$ columns which is possibly due to an increase in the fire numbers and intensities. Strong enhancements are also observed over India and to a lesser extent over Burma, Manchuria and Mexico, which can be at least partly related to biomass burning. In contrast, biomass burning is unlikely to be a dominant source in the Northern Hemisphere except in some regions (Kazakhstan, East Russia, Alaska) during JJA. It can be seen that $\mathrm{CH}_{3} \mathrm{OH}$ concentrations are progressively increasing from winter (DJF) to summertime (JJA). This can be explained by the seasonal cycle of the vegetation source which presents a maximum in late spring (Schade and Goldstein, 2006; Rinsland et al., 2009). During fall (SON), $\mathrm{CH}_{3} \mathrm{OH}$ concentrations decrease again in the Northern Hemisphere and increase in the Southern Hemisphere. Again, biomass burning is likely responsible for the strong enhancements in South America, Congo and Northern Australia.

Although biomass burning is assumed to be a weak emission source of methanol (accounting for less than 5\% of total emissions according to current inventories Jacob et al., 2005), the main hot spots in the global distributions could possibly be related to fires. This could be caused by the fact that methanol emitted by fire events is usually transported higher in the troposphere where the IASI sensitivity is larger or by the fact that a better sensitivity near the surface is induced because of higher surface temperatures for burning areas. This is consistent with the fact that biomass burning has been found to be a significant source of methanol in the upper troposphere (Dufour et al., 2007). The assimilation of 

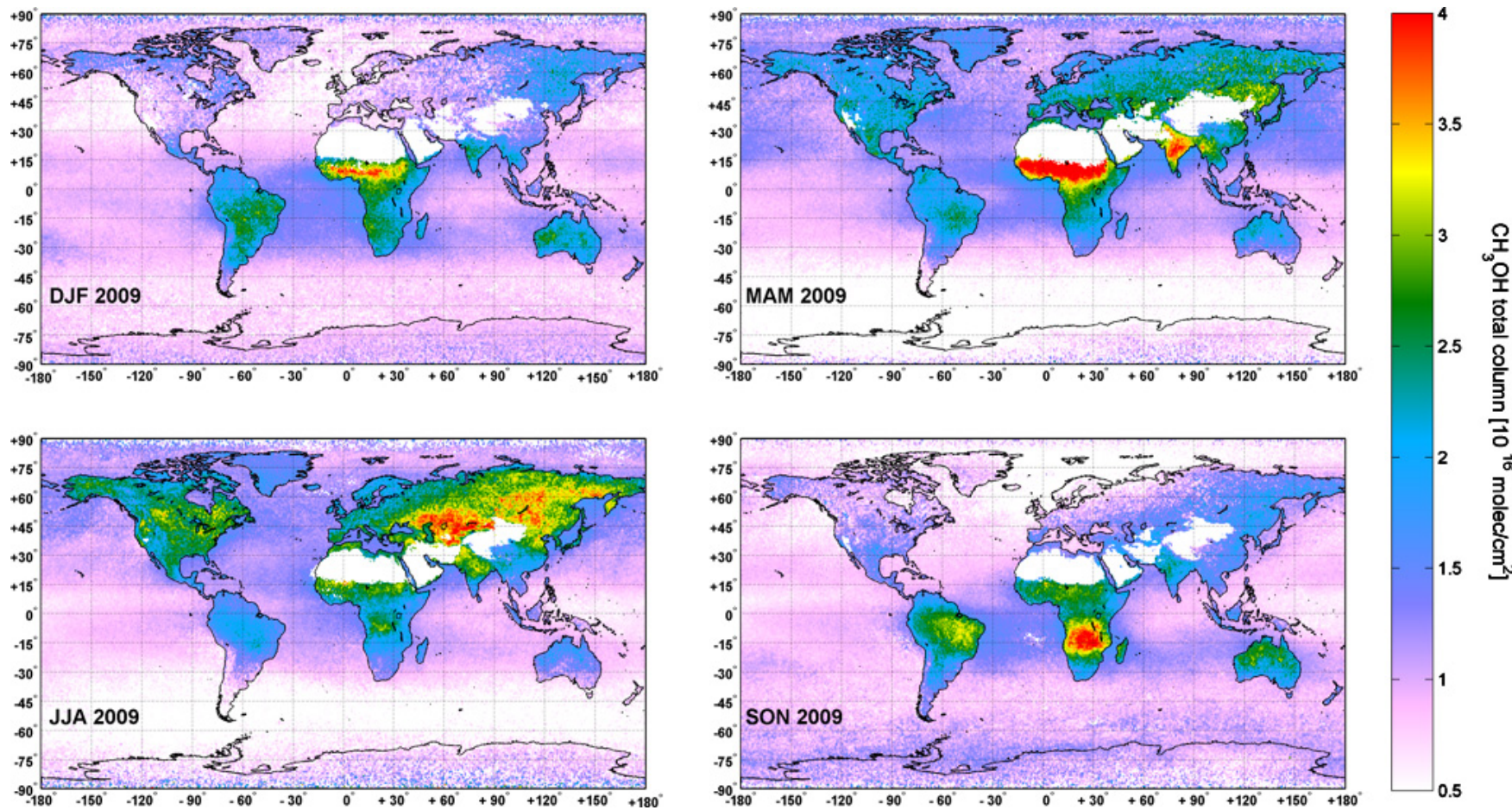

Fig. 6. Seasonal distributions of methanol total columns for the year 2009. The white areas correspond to a filter for sandy scenes where emissivity is uncertain.

IASI data into models should help determining the respective contributions of biogenic and fire emissions to the global methanol budget.

\subsection{Error assessment}

One of the disadvantages of the method described above is that it does not provide an estimate of the errors associated with the retrieved total columns. Because we are deriving the $\mathrm{CH}_{3} \mathrm{OH}$ columns from a weak signal, the associated error is expected to be quite large. An estimate of the error on the $\mathrm{CH}_{3} \mathrm{OH}$ columns derived from IASI can be based on forward simulations. For this purpose, we used a large set of different atmospheres compiled in an ECMWF database (Chevallier, 2001). Different input profiles are used for $\mathrm{CH}_{3} \mathrm{OH}$, corresponding to the different continental profiles taken from the IMAGESv2 model. The total columns used as input for the simulations are then compared to those retrieved from the simulated spectra using the same method as described above. The difference between the two columns gives a fair estimate of the absolute column errors. We do not expect these errors to be systematic on a global yearly scale but they cannot be excluded in particular circumstances such as in the presence of extreme values of ozone or water vapor.

It turns out that this absolute difference increases when the amount of $\mathrm{CH}_{3} \mathrm{OH}$ in the boundary layer (between the surface and $3 \mathrm{~km}$ height) increases. It follows that the high concentrations of methanol in the boundary layer (close to the emission sources) will not be well reproduced by the $\Delta T_{\mathrm{b}}$ method. This is consistent with the averaging kernel shape and the well known limited sensitivity of the infrared measurements toward low altitudes. Figure 7 shows the histogram of the relative difference between the total columns used as input in the forward simulations and the calculated ones. Negative differences imply that the retrieved total column from $\Delta T_{\mathrm{b}}$ is lower than the a priori value. Moreover, differences lower than $-100 \%$ are found but correspond only to methanol total columns which are below the detection limit of IASI (i.e. $1.60 \times 10^{16} \mathrm{molec} \mathrm{cm}^{-2}$ ). The distribution is similar to a normal distribution with a mean very close to zero $(0.6 \%)$. The standard deviation $(48.9 \%)$ provides our best estimate of the relative error on the retrieved methanol total column. This value is, however, clearly a lower bound for regions located close to emission sources and with low thermal contrast. In these regions, based on our analysis, errors as high as $100 \%$ are likely.

\section{Formic acid retrieval and distributions}

\subsection{Retrieval settings and errors}

In the case of formic acid, the target channel for brightness temperature has been chosen in the Q-branch at $1105.0 \mathrm{~cm}^{-1}$ which is the strongest absorption feature detectable in the IASI spectrum. The reference channels were chosen on both 


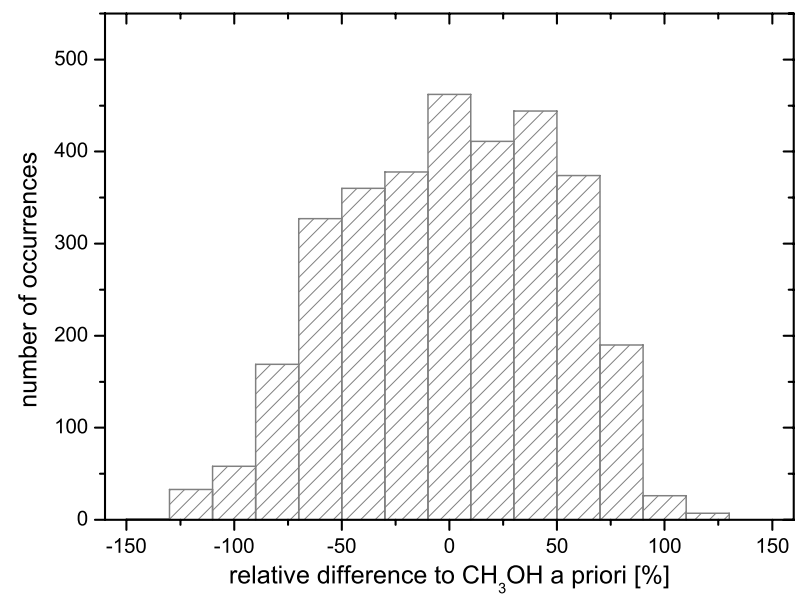

Fig. 7. Histogram of the relative differences between the simulated $\mathrm{CH}_{3} \mathrm{OH}$ total columns and the total columns derived from the $\Delta T_{\mathrm{b}}$ calculation.

sides at 1103.0 and $1109.0 \mathrm{~cm}^{-1}$. The $\Delta T_{\mathrm{b}}$ values computed globally over one year range from about 0 to $5 \mathrm{~K}$. As there exist large uncertainties on the vertical profile of formic acid, we have chosen here to rely on a composite vertical profile for the a priori. It was built from aircraft measurements for the low and free troposphere and from ACE-FTS for the upper troposphere. The a priori profile is an average of profiles collected over the USA $\left(25-55^{\circ} \mathrm{N}, 230-290^{\circ} \mathrm{E}\right)$ including (i) aircraft data from the INTEX-B C-130 campaign in April and May 2006 (Kleb et al., 2011) between 0-5 km, (ii) the arithmetic mean between INTEX-B data and ACE-FTS data (Abad et al., 2009) measured from March to May for altitudes between 6 and $8 \mathrm{~km}$, (iii) and an averaged ACE-FTS profile between 9 and $11 \mathrm{~km}$. The resulting profile, illustrated in Fig. 8, has a surface mixing ratio of about 750 pptv, which smoothly decreases as the altitude increases, down to less than $100 \mathrm{pptv}$ above $7 \mathrm{~km}$. Concentration above $11 \mathrm{~km}$ have been linearly extrapolated up to $20 \mathrm{~km}$.

As in the case of methanol, conversion factors between the $\Delta T_{\mathrm{b}}$ and the $\mathrm{HCOOH}$ total columns were tentatively derived based on OEM retrievals in selected regions around the world. Because of the weak signal and the presence of water vapor interferences, the retrievals are unstable and lead to large errors. Forward simulations using the ECMWF database and varying the $\mathrm{HCOOH}$ concentrations (by scaling the profile, resulting in a variability of about $350 \%$ ) were conducted to compute the relative difference between the true columns (input of the forward model) and those retrieved from the $\Delta T_{\mathrm{b}}$. Figure 9 illustrates in gray the histogram of these relative differences. The mode of the differences is located at about $60.0 \%$ suggesting a strong bias between the calculated and simulated total columns. Therefore, an alternative method has been used to derive the conversion factor between the $\Delta T_{\mathrm{b}}$ and the total columns. Relying only on the

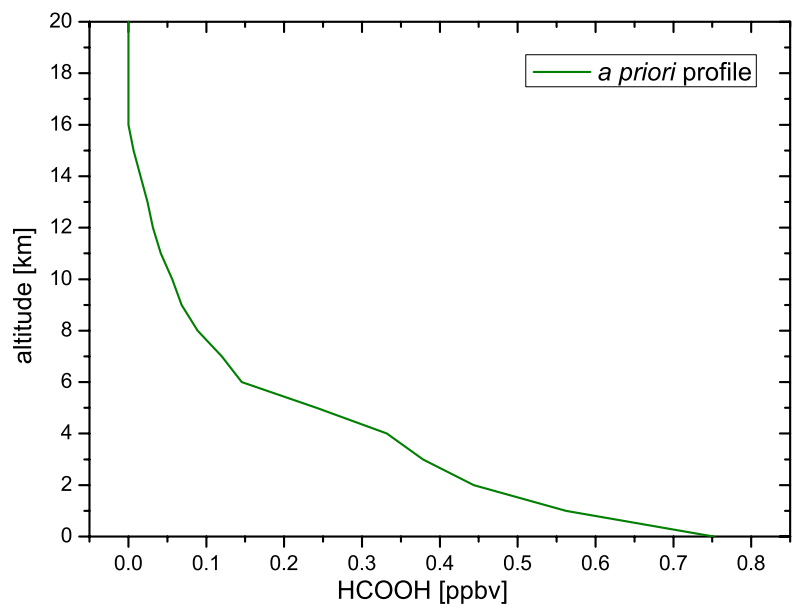

Fig. 8. HCOOH a priori profile derived from the combined aircraft and ACE measurements. See text for details.

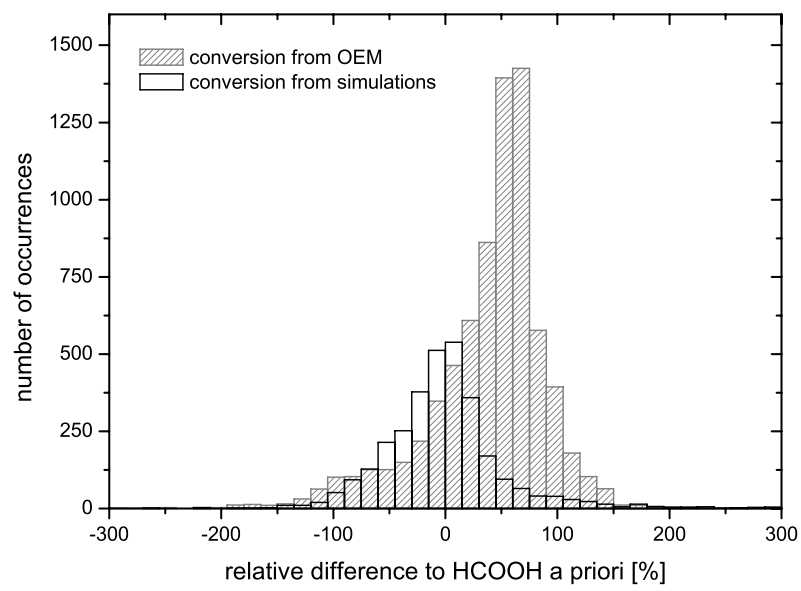

Fig. 9. Histograms of the relative differences between the simulated total columns of $\mathrm{HCOOH}$ and the $\mathrm{HCOOH}$ total columns obtained from brightness temperature differences. The gray histogram is derived from the conversion which uses OEM retrievals and the black one corresponds to the conversion obtained with simulated data. The latter, which is much less biased is used to obtain the global distributions (see Sect. 4.2).

forward calculations, it minimizes also the dependence upon the water vapor content $\left(C_{\mathrm{H}_{2} \mathrm{O}}\right.$ expressed in molec $\left.\mathrm{cm}^{-2}\right)$ and accounts for the varying sensitivity of the measurement to the local thermal contrast $(\tau)$. The following equation is used

$C_{\mathrm{HCOOH}}=\frac{\Delta T_{\mathrm{b}}-b_{1} \tau-b_{2} \tau C_{\mathrm{H}_{2} \mathrm{O}}-c_{1} C_{\mathrm{H}_{2} \mathrm{O}}-c_{2}}{a_{1} \tau+a_{2} \tau C_{\mathrm{H}_{2} \mathrm{O}}}$

with the parameters:

$$
\begin{aligned}
& a_{1}=0.024, a_{2}=4 \times 10^{-26}, \\
& b_{1}=0.005, b_{2}=1 \times 10^{-26}, \\
& c_{1}=0.131 \times 10^{-23}, c_{2}=0.139,
\end{aligned}
$$



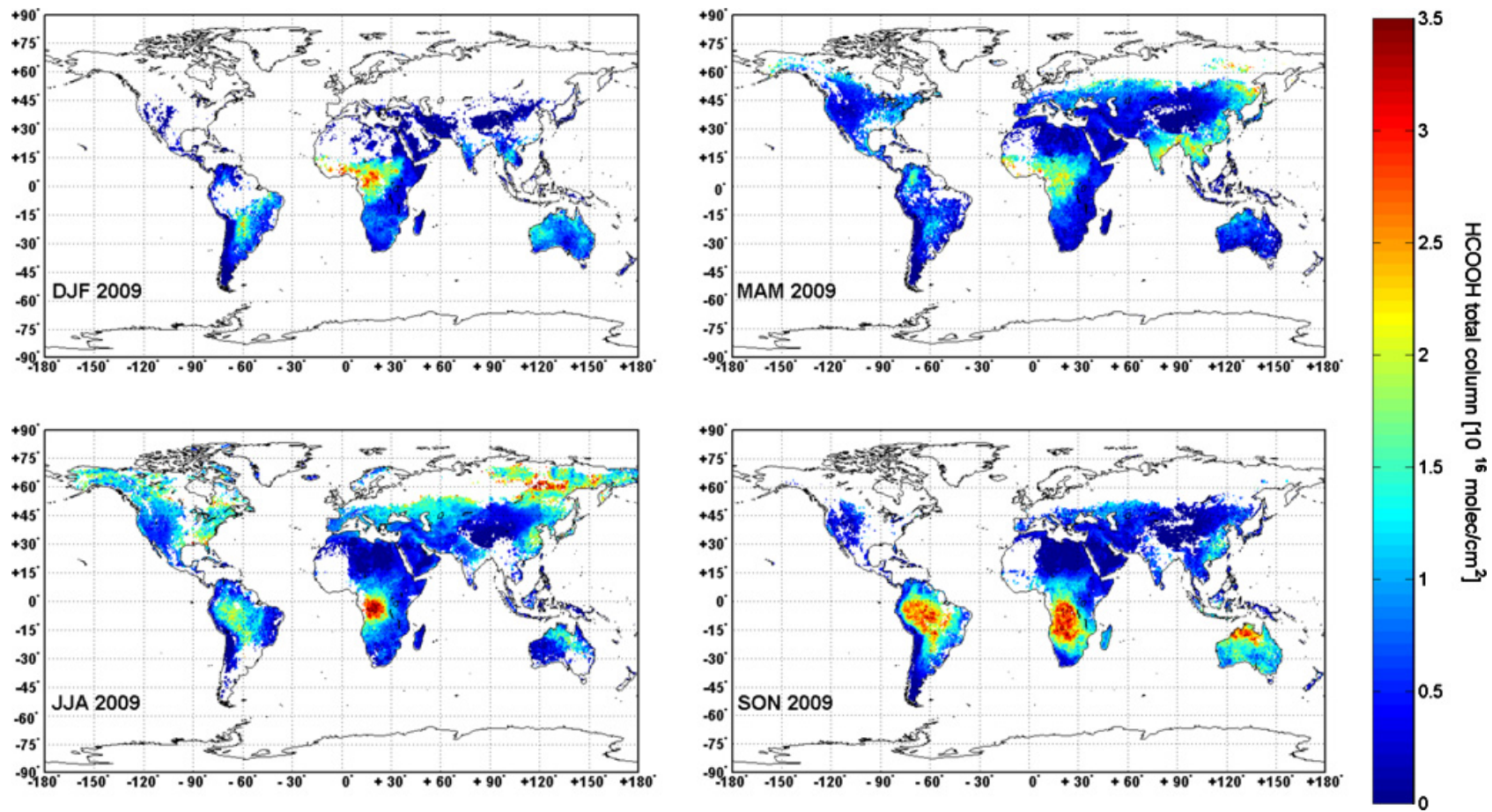

Fig. 10. Seasonal distributions of formic acid total columns for the year 2009. Only cloud free observations recorded during daytime above continents along with a thermal contrast higher than $5 \mathrm{~K}$ were considered.

and where $\mathrm{HCOOH}$ total columns $\left(C_{\mathrm{HCOOH}}\right)$ are expressed in $10^{16}$ molec $\mathrm{cm}^{-2}$. The thermal contrast $\tau$ corresponds to the difference between the surface temperature and the air temperature at the first retrieved altitude level, located at about $100 \mathrm{~m}$ (both included in the IASI level 2 data). This mapping of $\Delta T_{\mathrm{b}}$ onto total columns of $\mathrm{HCOOH}$ provides much better results. However a significant dependency on the thermal contrast remains, with lower errors found for higher thermal contrast values. We have chosen to consider only the cases for which the thermal contrast is higher than $5 \mathrm{~K}$. This conservative criterion excludes all retrievals above oceans. The resulting histogram of the relative differences between the simulated and calculated $\mathrm{HCOOH}$ total columns is shown in black on Fig. 9. It is similar to a normal distribution, with its mean being equal to $-0.8 \%$. Our estimation of the error on the formic acid total column is given by the standard deviation of the differences, which is about $60 \%$. This error is only slightly higher than the error found for the $\mathrm{CH}_{3} \mathrm{OH}$ columns, but only applies here to favorable situations with large thermal contrast. Moreover, in the same way as methanol, the negative differences lower than $-100 \%$ correspond only to $\mathrm{HCOOH}$ total columns which are below the detection limit of IASI (and has been evaluated to be about $0.60 \times 10^{16}$ molec cm $^{-2}$ ).

This retrieval approach does not provide information about the vertical sensitivity of the formic acid total column. However, the limited set of full profile retrievals performed give a maximum sensitivity between 4 and $14 \mathrm{~km}$.

\subsection{Global distributions}

The global distributions of formic acid for the four seasons are illustrated in Fig. 10 , on a $0.5^{\circ} \times 0.5^{\circ}$ averaged grid. Only cloud free observations recorded during daytime and with a thermal contrast higher or equal to $5 \mathrm{~K}$ were taken into account. The latter constraint removes unfortunately many observations at high latitudes (no observations above about $45^{\circ} \mathrm{N}$ in winter and about $65^{\circ} \mathrm{N}$ during summer). Grid points which include less than ten $\mathrm{HCOOH}$ measurements were also filtered out. As for $\mathrm{CH}_{3} \mathrm{OH}$, clear seasonal variations are observed. The retrieved $\mathrm{HCOOH}$ total columns range from background values of less than $0.5 \times 10^{16} \mathrm{molec}^{-2}$ above Europe and North America to $5 \times 10^{16} \mathrm{molec} \mathrm{cm}^{-2}$ above fire events, mainly during summer 2009 in Africa. These high formic acid total columns in fire plumes are in good agreement with the values reported by Coheur et al. (2009) and Worden et al. (1997) if we account for the factor 2 resulting from the use of the improved line parameters (Vander Auwera et al., 2007).

The 2009 northern hemispheric winter season (DJF) shows the lowest number of observations. Comparing with AATSR fire counts during that period, we found that enhancements of $\mathrm{HCOOH}$ in the western-central region of Africa and to a lesser extent in South America might be partly due to biomass burning. During spring (MAM), we observe a decrease in the $\mathrm{HCOOH}$ total columns above Africa and South America together with a fire count decrease. 
High concentrations are also found in Asia (India, Burma and Manchuria) which are well correlated with $\mathrm{CH}_{3} \mathrm{OH}$ hot spots. The peak of the biomass burning season in South America and Southern Africa happens usually around August-September whereas in Australia most of the burning occurs around October-November (Gloudemans et al., 2006). Together with the minimal washout of $\mathrm{HCOOH}$ occurring during the dry season, it probably largely explains the high $\mathrm{HCOOH}$ total columns observed during JJA above Congo and Brazil as well as in Northern Australia during the SON period. The overall increase of formic acid in the Northern Hemisphere during JJA is likely caused by the seasonality of its biogenic emissions. However, according to the AATSR fire count distributions, some regions with large $\mathrm{HCOOH}$ columns may be associated with boreal fires such as in Eastern Russia and in Alaska. Finally, the very widespread hot spots found during SON above Amazonia and Central Africa do not seem to be only related to fires and very likely points also to biogenic emissions of either $\mathrm{HCOOH}$ or $\mathrm{HCOOH}$ precursors. Throughout the year (MAM through SON, no available data for DJF), large $\mathrm{HCOOH}$ columns are observed in Eastern China which may partly be due to anthropogenic activities. Several common patterns are also found in the distributions of $\mathrm{HCOOH}$ and $\mathrm{CH}_{3} \mathrm{OH}$ columns, probably due to their common emission sources (such as biomass burning and plant growth). Also note that the seasonality observed here is in good agreement with that reported from ACE-FTS (Abad et al., 2009) and from MIPAS (Grutter et al., 2010).

\section{Seasonal variations in relation to biomass burning}

In this section we compare the 2009 time series of methanol, formic acid and carbon monoxide for three selected regions subject to biomass burning. The vertical sensitivity profiles of IASI for these three species are all maximum in the free troposphere, i.e. between 4 to $14 \mathrm{~km}, 6$ to $10 \mathrm{~km}$ and between 3 to $12 \mathrm{~km}$ for $\mathrm{HCOOH}, \mathrm{CH}_{3} \mathrm{OH}$ and $\mathrm{CO}$ total columns, respectively. The comparisons are therefore most likely to reflect similarities/differences in the free tropospheric columns but fine structures in the respective profiles could be missed. Monthly mean total columns of methanol and formic acid are shown in Fig. 11 together with the total columns of carbon monoxide and the AATSR fire counts for three $10^{\circ} \times 10^{\circ}$ regions located in Brazil $\left(15-5^{\circ} \mathrm{S}, 60-50^{\circ} \mathrm{W}\right)$, Congo $\left(15-5^{\circ} \mathrm{S}, 20-30^{\circ} \mathrm{E}\right)$ and South-East Asia $\left(20-30^{\circ} \mathrm{N}, 95-\right.$ $105^{\circ} \mathrm{E}$ ). For each regions, the time series of $\mathrm{CO}, \mathrm{CH}_{3} \mathrm{OH}$ and $\mathrm{HCOOH}$ are similar. An increase in the total columns is observed for the three species just after the month with the maximum fire counts. This delay may be induced by the fact that the probed air masses are located in the free troposphere and are therefore subject to some transport which could result in the spreading of the species or the spatial displacement of the maxima. The highest number of fires (ex-

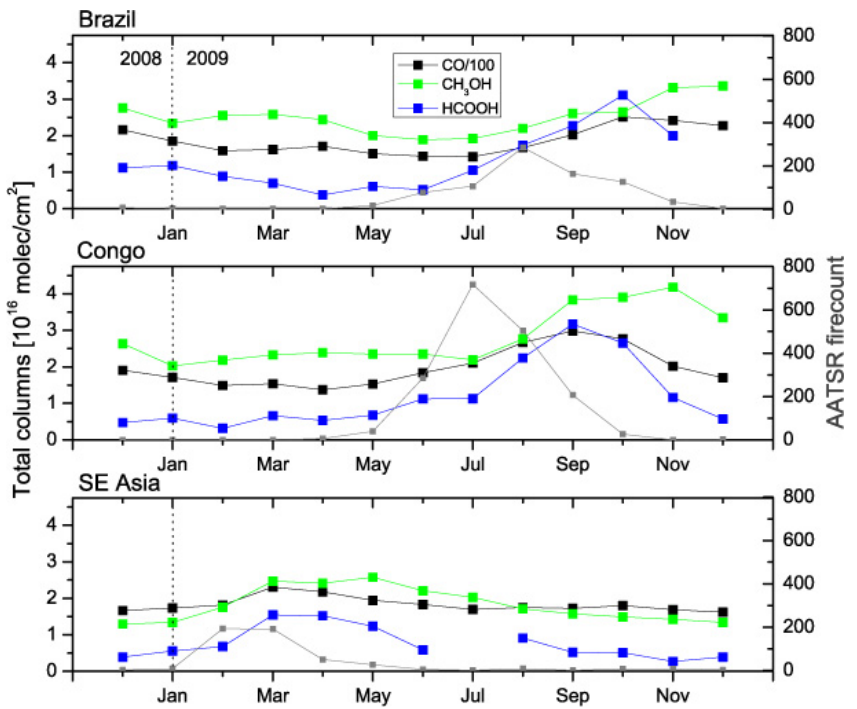

Fig. 11. Time series of methanol (green curve), formic acid (blue curve) and carbon monoxide (black curve) monthly mean total columns for three different areas associated with biomass burning (Brazil, Congo and SE Asia). Carbon monoxide total columns where divided by 100 for comparison. The left scale and gray curves correspond to the sum of the AATSR fire counts for each months.

ceeding 700) is found above Congo where methanol, formic acid and carbon monoxide reach high values, with increases of about $1.6 \times 10^{16} 2.5 \times 10^{16}$ and $1.4 \times 10^{18}$ molec cm $^{-2}$ in comparison with their mean total column between January and June, respectively. In each cases, the $\mathrm{CH}_{3} \mathrm{OH}$ maximum lasts longer than for $\mathrm{CO}$ or $\mathrm{HCOOH}$. This cannot be explained by its lifetime which is similar to formic acid in the free troposphere (about one week) but suggests an additional source or transport to this region. Overall higher concentrations of $\mathrm{CH}_{3} \mathrm{OH}$ found above Brazil and Congo may also be due to the larger biogenic source in these regions.

In addition to looking into correlations regionally, preliminary global analyses were carried out. Linear correlations $\left(R^{2}=0.7\right.$ ) between $\mathrm{CH}_{3} \mathrm{OH}$ and $\mathrm{HCOOH}$ were found during the DJF and SON periods highlighting specific emissions or fate of these two species.

\section{Conclusions and perspectives}

In this study, we have retrieved methanol and formic acid from the data provided by the IASI sounder. Using a radiance indexing method and the calculation of brightness temperature differences, first global distributions are computed. They are provided as total columns, after careful conversion of the brightness temperature differences. The conversion has been achieved based on a set of retrievals in selected regions for methanol and on forward simulations for formic 
acid. Taking full advantage of the IASI spatial and temporal coverage, unprecedented information on the location and origin of sources have been acquired.

The simple retrieval method used here does not allow the determination of individual error for each observations. We have estimated, using a large set of representative forward calculation, global errors of about typically $50 \%$ and $60 \%$ for the methanol and formic acid total columns, respectively. Although these errors are significant, this robust method takes advantage of the very large number of IASI measurements at low computational cost. In this way, we provide global observations for these two volatile organic compounds.

The global distributions shown in this study highlight strong seasonal variations for methanol and formic acid with maximum total column values evaluated at 5.4 and $5.0 \times 10^{16} \mathrm{molec} \mathrm{cm}^{-2}$, respectively. The strong enhancements seen in the global maps might be largely attributed to biomass burning (mostly in tropical regions). The main seasonal patterns, especially at mid-latitudes where we find higher columns in spring and summer, might be explained by variations in biogenic emissions and increased plant growth. Anthropogenic emissions could not been clearly identified in these distributions.

Time series of methanol, formic acid, carbon monoxide and AATSR fire counts were also compared and found to be fairly well correlated for three different regions (Congo, Brazil and South-East Asia) where biomass burning is their likely common source.

It is anticipated that the assimilation of these data in a global chemistry model will help to improve the determination of the emission fluxes for these two species. Mean averaging kernels for methanol (differentiated for land and ocean) are provided in order to account for the vertical sensitivity of the measurements.

Acknowledgements. IASI has been developed and built under the responsibility of the Centre National d'Etudes Spatiales (CNES, France). It is flown onboard the MetOp satellites as part of the EUMETSAT Polar System. The IASI L1 data are received through the EUMETCast near real time data distribution service. The research in Belgium was funded by the "Communauté Française de Belgique - Actions de Recherche Concertées", the Fonds National de la Recherche Scientifique (FRS-FNRS F.4511.08), the Belgian Science Policy Office and the European Space Agency (ESA-Prodex C90-327). The ACE mission is funded primarily by the Canadian Space Agency.

Edited by: C. McNeil

\section{References}

Abad, G. G., Bernath, P. F., Boone, C. D., McLeod, S. D., Manney, G. L., and Toon, G. C.: Global distribution of upper tropospheric formic acid from the ACE-FTS, Atmos. Chem. Phys., 9, 80398047, doi:10.5194/acp-9-8039-2009, 2009.

Arino, O., Plummer, S., and Defrenne, D.: Fire disturbance: the ten years time series of the ATSR World Fire Atlas, in: ATSR Workshop, 26-30, 2005.

Arlander, D., Cronn, D., Farmer, J., Menzia, F., and Westberg, H.: Gaseous oxygenated hydrocarbons in the remote marine troposphere, J. Geophys. Res., 95, 16391-16403, 1990.

Atkinson, R.: Kinetics and mechanisms of the gas-phase reactions of the hydroxyl radical with organic compounds under atmospheric conditions, Chem. Rev., 86, 69-201, 1986.

Atkinson, R. and Arey, J.: Atmospheric degradation of volatile organic compounds, Chem. Rev., 103, 4605-4638, 2003.

Beer, R., Shephard, M., Kulawik, S., Clough, S., Eldering, A., Bowman, K., Sander, S., Fisher, B., Payne, V., Luo, M., Osterman, G., and Worden, J.: First satellite observations of lower tropospheric ammonia and methanol, Geophys. Res. Lett., 35, L09801, doi:10.1029/2008GL033642, 2008.

Boynard, A., Clerbaux, C., Coheur, P.-F., Hurtmans, D., Turquety, S., George, M., Hadji-Lazaro, J., Keim, C., and Mayer-Arnek, J.: Measurements of total and tropospheric ozone from the IASI instrument: comparison with satellite and ozone sonde observations, Atmos. Chem. Phys., 9, 6255-6271, doi:10.5194/acp-96255-2009, 2009.

Brunner, A., Ammann, C., Neftel, A., and Spirig, C.: Methanol exchange between grassland and the atmosphere, Biogeosciences, 4, 395-410, doi:10.5194/bg-4-395-2007, 2007.

Butkovskaya, N., Pouvesle, N., Kukui, A., and Le Bras, G.: Mechanism of the OH-Initiated Oxidation of Glycolaldehyde over the Temperature Range 233-296 K, J. Phys. Chem. A, 110, 13492 13499, 2006a.

Butkovskaya, N., Pouvesle, N., Kukui, A., Mu, Y., and Le Bras, G.: Mechanism of the OH-Initiated Oxidation of Hydroxyacetone over the Temperature Range 236-298 K, J. Phys. Chem. A, 110, 6833-6843, 2006b.

Chameides, W. and Davis, D.: Aqueous-phase source of formic acid in clouds, Nature, 304, 427-429, 1983.

Chance, K., Palmer, P. I., Spurr, R. J., Martin, R., Kurosu, T. P., and Jacob, D. J.: Satellite observations of formaldehyde over North America from GOME, Geophys. Res. Lett., 27, 34613464, 2000.

Charlson, R., Lovelock, J., Andreae, M., and Warren, S.: Oceanic phytoplankton, atmospheric sulphur, cloud albedo and climate, Nature, 326, 16, 1987.

Chevallier, F.: Sampled databases of 60-level atmospheric profiles from the ECMWF analysis, Tech. Rep. Research Report No. 4, Eumetsat/ECMWF SAF Programme, 2001.

Clarisse, L., Coheur, P.-F., Prata, A. J., Hurtmans, D., Razavi, A., Hadji-Lazaro, J., Clerbaux, C., and Phulpin, T.: Tracking and quantifying volcanic $\mathrm{SO}_{2}$ with IASI, the September 2007 eruption at Jebel-at-Tair, Atmos. Chem. Phys., 8, 7723-7734, doi:10.5194/acp-8-7723-2008, 2008.

Clarisse, L., Clerbaux, C., Dentener, F., Hurtmans, D., and Coheur, P.-F.: Global ammonia distribution derived from infrared satellite observations, Nat. Geosci., 2, 479-483, doi:doi:10.1038/ ngeo551, 2009. 
Clarisse, L., Shephard, M., Dentener, F., Hurtmans, D., CadyPereira, K., Karagulian, F., Van Damme, M., Clerbaux, C., and Coheur, P.-F.: Satellite monitoring of ammonia: A case study of the San Joaquin Valley, J. Geophys. Res., 115, D13302, doi:10.1029/2009JD013291, 2010.

Clerbaux, C., Boynard, A., Clarisse, L., George, M., Hadji-Lazaro, J., Hurtmans, D., Herbin, H., Pommier, M., Razavi, A., Turquety, S., Wespes, C., and Coheur, P.-F.: Monitoring of atmospheric composition using the thermal infrared IASI/METOP sounder, Atmos. Chem. Phys., 9, 6041-6054, doi:10.5194/acp-9-60412009, 2009.

Coheur, P.-F., Barret, B., Turquety, S., Hurtmans, D., Hadji-Lazaro, J., and Clerbaux, C.: Retrieval and characterization of ozone vertical profiles from a thermal infrared nadir sounder, J. Geophys. Res., 5, 4599-4639, 2005.

Coheur, P., Herbin, H., Clerbaux, C., Hurtmans, D., Wespes, C., Carleer, M., Turquety, S., Rinsland, C., Remedios, J., Hauglustaine, D., Boone, C., and P.F., B.: ACE-FTS observation of a young biomass burning plume: first reported measurements of $\mathrm{C}_{2} \mathrm{H}_{4}, \mathrm{C}_{3} \mathrm{H}_{6} \mathrm{O}, \mathrm{H}_{2} \mathrm{CO}$ and PAN by infrared occultation from space, Atmos. Chem. Phys., 7, 5437-5446, doi:10.5194/acp-75437-2007, 2007.

Coheur, P.-F., Clarisse, L., Turquety, S., Hurtmans, D., and Clerbaux, C.: IASI measurements of reactive trace species in biomass burning plumes, Atmos. Chem. Phys., 9, 5655-5667, doi:10.5194/acp-9-5655-2009, 2009.

De Smedt, I., Müller, J., Stavrakou, T., van der A, R., Eskes, H., and Van Roozendael, M.: Twelve years of global observations of formaldehyde in the troposphere using GOME and SCIAMACHY sensors, Atmos. Chem. Phys., 8, 4947-4963, doi:10.5194/acp-8-4947-2008, 2008.

Dufour, G., Boone, C. D., Rinsland, C. P., and Bernath, P. F.: First space-borne measurements of methanol inside aged southern tropical to mid-latitude biomass burning plumes using the ACE-FTS instrument, Atmos. Chem. Phys., 6, 3463-3470, doi:10.5194/acp-6-3463-2006, 2006.

Dufour, G., Szopa, S., Hauglustaine, D. A., Boone, C. D., Rinsland, C. P., and Bernath, P. F.: The influence of biogenic emissions on upper-tropospheric methanol as revealed from space, Atmos. Chem. Phys., 7, 6119-6129, doi:10.5194/acp-7-61192007, 2007.

Eerdekens, G., Ganzeveld, L., Vilá-Guerau de Arellano, J., Klüpfel, T., Sinha, V., Yassaa, N., Williams, J., Harder, H., Kubistin, D., Martinez, M., and Lelieveld, J.: Flux estimates of isoprene, methanol and acetone from airborne PTR-MS measurements over the tropical rainforest during the GABRIEL 2005 campaign, Atmos. Chem. Phys., 9, 4207-4227, doi:10.5194/acp-9-42072009, 2009.

Feingold, G., Eberhard, W., Veron, D., and Previdi, M.: First measurements of the Twomey indirect effect using ground-based remote sensors, Geophys. Res. Lett., 30, 1287, doi:10.1029/2002GL016633, 2003.

Filella, I. and Peņuelas, J.: Daily, weekly, and seasonal time courses of VOC concentrations in a semi-urban area near Barcelona, Atmos. Environ., 40, 7752-7769, 2006.

Fischer, H., de Reus, M., Traub, M., Williams, J., Lelieveld, J., de Gouw, J., Warneke, C., Schlager, H., Minikin, A., Scheele, R., and Siegmund, P.: Deep convective injection of boundary layer air into the lowermost stratosphere at midlatitudes, Atmos.
Chem. Phys., 3, 739-745, doi:10.5194/acp-3-739-2003, 2003.

Fu, T., Jacob, D., Palmer, P., Chance, K., Wang, Y., Barletta, B., Blake, D., Stanton, J., and Pilling, M.: Space-based formaldehyde measurements as constraints on volatile organic compound emissions in east and south Asia and implications for ozone, J. Geophys. Res., 112, D06312, doi:10.1029/2006JD007853, 2007.

Galbally, I. and Kirstine, W.: The production of methanol by flowering plants and the global cycle of methanol, J. Atmos. Chem., 43, 195-229, 2002.

George, M., Clerbaux, C., Coheur, P.-F., Hadji-Lazaro, J., Hurtmans, D., Pommier, M., Turquety, S., Edwards, D., Worden, H., Luo, M., Rinsland, C. P., and Barnet, C.: Carbon monoxide distributions from the IASI/METOP mission : evaluation with other spaceborne remote sensors, Atmos. Chem. Phys., 9, 8317-8330, doi:10.5194/acp-9-8317-2009, 2009.

Glatthor, N., Von Clarmann, T., Fischer, H., Funke, B., Grabowski, U., Höpfner, M., Kellmann, S., Kiefer, M., Linden, A., Milz, M., et al.: Global peroxyacetyl nitrate(PAN) retrieval in the upper troposphere from limb emission spectra of the Michelson Interferometer for Passive Atmospheric Sounding (MIPAS), Atmos. Chem. Phys., 7, 2775-2787, doi:10.5194/acp-7-2775-2007, 2007.

Glatthor, N., Von Clarmann, T., Stiller, G., Funke, B., Koukouli, M., Fischer, H., Grabowski, U., Höpfner, M., Kellmann, S., and Linden, A.: Large-scale upper tropospheric pollution observed by MIPAS HCN and $\mathrm{C}_{2} \mathrm{H}_{6}$ global distributions, Atmos. Chem. Phys., 9, 9619-9634, doi:10.5194/acp-9-9619-2009, 2009.

Gloudemans, A., Krol, M., Meirink, J., De Laat, A., Van der Werf, G., Schrijver, H., Van den Broek, M., and Aben, I.: Evidence for long-range transport of carbon monoxide in the Southern Hemisphere from SCIAMACHY observations, Geophys. Res. Lett., 33, 16807, doi:10.1029/2006GL026804, 2006.

Goldman, A., Murcray, F., Murcray, D., and Rinsland, C.: A search for formic acid in the upper troposphere: A tentative identification of the $1105 \mathrm{~cm}^{-1} v_{6}$ band Q-branch in highresolution balloon-borne solar absorption spectra, Geophys. Res. Lett, 11, 307-310, 1984.

Goode, J., Yokelson, R., Ward, D., Susott, R., Babbitt, R., Davies, M., and Hao, W.: Measurements of excess $\mathrm{O}_{3}, \mathrm{CO}_{2}, \mathrm{CO}, \mathrm{CH}_{4}$, $\mathrm{C}_{2} \mathrm{H}_{4}, \mathrm{C}_{2} \mathrm{H}_{2}, \mathrm{HCN}, \mathrm{NO}, \mathrm{NH}_{3}, \mathrm{HCOOH}, \mathrm{CH}_{3} \mathrm{COOH}, \mathrm{HCHO}$, and $\mathrm{CH}_{3} \mathrm{OH}$ in 1997 Alaskan biomass burning plumes by airborne Fourier transform infrared spectroscopy (AFTIR), J. Geophys. Res., 105, 22147, doi:10.1029/2000JD900287, 2000.

Graedel, T. and Eisner, T.: Atmospheric formic acid from formicine ants: a preliminary assessment, Tellus B, 40, 335-339, 1988.

Granby, K., Christensen, C., and Lohse, C.: Urban and semi-rural observations of carboxylic acids and carbonyls, Atmos. Environ., 31, 1403-1415, 1997.

Grosjean, D.: Organic acids in southern California air: ambient concentrations, mobile source emissions, in situ formation and removal processes, Environ. Sci. Technol., 23, 1506-1514, 1989.

Grosjean, D.: Formic acid and acetic acid measurements during the Southern California Air Quality Study, Atmos. Environ., 24, 2699-2702, 1990.

Grutter, M., Glatthor, N., Stiller, G., Fischer, H., Grabowski, U., Höpfner, M., Kellmann, S., Linden, A., and von Clarmann, T.: Global distribution and variability of formic acid as observed by MIPAS-ENVISAT, J. Geophys. Res., 115, D10303, doi:10.1029/2009JD012980, 2010. 
Harley, P., Greenberg, J., Niinemets, U., and Guenther, A.: Environmental controls over methanol emission from leaves, Biogeosciences, 4, 1083-1099, doi:10.5194/bg-4-1083-2007, 2007.

Hartmann, W., Santana, M., Hermoso, M., Andreae, M., and Sanhueza, E.: Diurnal cycles of formic and acetic acids in the northern part of the Guayana shield, Venezuela, J. Atmos. Chem., 13, 63-72, 1991.

Heald, C., Henze, D., Horowitz, L., Feddema, J., Lamarque, J., Guenther, A., Hess, P., Vitt, F., Seinfeld, J., Goldstein, A., and Fung, I.: Predicted change in global secondary organic aerosol concentrations in response to future climate, emissions, and land use change, J. Geophys. Res., 113, D05211, doi:10.1029/2007JD009092, 2008.

Heikes, B., Chang, W., Pilson, M., Swift, E., Singh, H., Guenther, A., Jacob, D., Field, B., Fall, R., Riemer, D., et al.: Atmospheric methanol budget and ocean implication, Global Biogeochem. Cy., 16, 1133, doi:10.1029/2002GB001895, 2002.

Helas, G., Bingemer, H., and Andrea, M.: Organic acids over equatorial Africa - Results from DECAFE 88, J. Geophys. Res., 97, 6187-6193, 1992.

Herbin, H., Hurtmans, D., Clarisse, L., Turquety, S., Clerbaux, C., Rinsland, C., Boone, C., Bernath, P., and Coheur, P.: Distributions and seasonal variations of tropospheric ethene $\left(\mathrm{C}_{2} \mathrm{H}_{4}\right)$ from Atmospheric Chemistry Experiment (ACE-FTS) solar occultation spectra, Geophys. Res. Lett., 36, L04801, doi:10.1029/2008GL036338, 2009.

Hermans, I., Müller, J., Nguyen, T., Jacobs, P., and Peeters, J.: Kinetics of [alpha]-Hydroxy-alkylperoxyl Radicals in Oxidation Processes. $\mathrm{HO}_{2} \bullet-$ Initiated Oxidation of Ketones/Aldehydes near the Tropopause, J. Phys. Chem., 109, 4303-4311, 2005.

Herndon, S., Zahniser, M., Nelson Jr, D., Shorter, J., McManus, J., Jiménez, R., Warneke, C., and de Gouw, J.: Airborne measurements of $\mathrm{HCHO}$ and $\mathrm{HCOOH}$ during the New England Air Quality Study 2004 using a pulsed quantum cascade laser spectrometer, J. Geophys. Res., 112, D10S03, doi:10.1029/2006JD007600, 2007.

Holzinger, R., Williams, J., Salisbury, G., Klüpfel, T., De Reus, M., Traub, M., Crutzen, P., and Lelieveld, J.: Oxygenated compounds in aged biomass burning plumes over the Eastern Mediterranean: evidence for strong secondary production of methanol and acetone, Atmos. Chem. Phys., 4, 6321-6340, doi:10.5194/acp-4-6321-2005, 2005.

Houweling, S., Dentener, F., and Lelieveld, J.: The impact of nonmethane hydrocarbon compounds on tropospheric photochemistry, J. Geophys. Res., 103, 673-10, 1998.

Jacob, D.: Chemistry of $\mathrm{OH}$ in remote clouds and its role in the production of formic acid and peroxymonosulfate, J. Geophys. Res., 91, 9807-9826, 1986.

Jacob, D. and Wofsy, S.: Photochemistry of biogenic emissions over the Amazon forest, J. Geophys. Res., 93, 1477-1486, 1988.

Jacob, D., Field, B., Li, Q., Blake, D., de Gouw, J., Warneke, C., Hansel, A., Wisthaler, A., Singh, H., and Guenther, A.: Global budget of methanol: Constraints from atmospheric observations, J. Geophys. Res., 110, D08303, doi:10.1029/2004JD005172, 2005.

Jaeglé, L., Jacob, D., Brune, W., Faloona, I., Tan, D., Heikes, B., Kondo, Y., Sachse, G., Anderson, B., Gregory, G., Singh, H., Pueschel, R., Ferry, G., Blake, D., and Shetter, R. E.: Photochemistry of $\mathrm{HO}_{\mathrm{x}}$ in the upper troposphere at northern midlati- tudes, Environ. Sci. Technol., 105(D3), 3877-3892, 2000.

Jordan, C., Fitz, E., Hagan, T., Sive, B., Frinak, E., Haase, K., Cottrell, L., Buckley, S., and Talbot, R.: Long-term study of VOCs measured with PTR-MS at a rural site in New Hampshire with urban influences, Atmos. Chem. Phys., 9, 4677-4697, doi:10.5194/acp-9-4677-2009, 2009.

Karl, T., Guenther, A., Spirig, C., Hansel, A., and Fall, R.: Seasonal variation of biogenic VOC emissions above a mixed hardwood forest in northern Michigan, Geophys. Res. Lett., 30, 2186 , doi:10.1029/2003GL018432, 2003.

Karl, T., Harley, P., Guenther, A., Rasmussen, R., Baker, B., Jardine, K., and Nemitz, E.: The bi-directional exchange of oxygenated VOCs between a loblolly pine (Pinus taeda) plantation and the atmosphere, Atmos. Chem. Phys., 5, 3015-3031, 2005, http://www.atmos-chem-phys.net/5/3015/2005/.

Karl, T., Guenther, A., Yokelson, R., Greenberg, J., Potosnak, M., Blake, D., and Artaxo, P.: The tropical forest and fire emissions experiment: Emission, chemistry, and transport of biogenic volatile organic compounds in the lower atmosphere over Amazonia, J. Geophys. Res., 112, D18302, doi:10.1029/2007JD008539, 2007.

Kawamura, K., Ng, L., and Kaplan, I.: Determination of organic acids $\left(\mathrm{C}_{1}-\mathrm{C}_{10}\right)$ in the atmosphere, motor exhausts, and engine oils, Environ. Sci. Technol., 19, 1082-1086, 1985.

Keene, W. and Galloway, J.: Organic acidity in precipitation of North America, Atmos. Environ., 18, 2491-2497, 1984.

Keene, W. and Galloway, J.: The biogeochemical cycling of formic and acetic acids through the troposphere: An overview of current understanding, Tellus B, 40, 322-334, 1988.

Khwaja, H.: Atmospheric concentrations of carboxylic acids and related compounds at a semiurban site, Atmos. Environ., 29, 127-139, 1995.

Kleb, M. M., Chen, G., Crawford, J. H., Flocke, F. M., and Brown, C. C.: An overview of measurement comparisons from the INTEX-B/MILAGRO airborne field campaign, Atmos. Meas. Tech., 4, 9-27, doi:10.5194/amt-4-9-2011, 2011.

MacDonald, R. and Fall, R.: Detection of substantial emissions of methanol from plants to the atmosphere, Atmos. Environ., 27, 1709-1713, 1993.

Martin, R., Westberg, H., Allwine, E., Ashman, L., Farmer, J., and Lamb, B.: Measurement of isoprene and its atmospheric oxidation products in a central Pennsylvania deciduous forest, J. Atmos. Chem., 13, 1-32, 1991.

Meinshausen, M., Hare, B., Wigley, T., Van Vuuren, D., Den Elzen, M., and Swart, R.: Multi-gas emissions pathways to meet climate targets, Clim. Change, 75, 151-194, 2006.

Millet, D., Jacob, D., Custer, T., de Gouw, J., Goldstein, A., Karl, T., Singh, H., Sive, B., Talbot, R., Warneke, C., and Williams, J.: New constraints on terrestrial and oceanic sources of atmospheric methanol, Atmos. Chem. Phys., 8, 6887-6905, doi:10.5194/acp-8-6887-2008, 2008a.

Millet, D., Jacob, D., Folkert Boersma, K., Fu, T.-M., Kurosu, T., Chance, K., Heald, C., and Guenther, A.: Spatial distribution of isoprene emissions from North America derived from formaldehyde column measurements by the OMI satellite sensor, J. Geophys. Res., 113, D02307, doi:doi:10.1029/2007JD008950, 2008b.

Monks, P.: Gas-phase radical chemistry in the troposphere, Chem. Soc. Rev., 34, 376-395, 2005. 
Moore, D. P. and Remedios, J. J.: Seasonality of Peroxyacetyl nitrate (PAN) in the upper troposphere and lower stratosphere using the MIPAS-E instrument, Atmos. Chem. Phys., 10, 6117-6128, 2010 , http://www.atmos-chem-phys.net/10/6117/2010/.

Moore, D. P., Remedios, J. J., and Waterfall, A. M.: Global distributions of acetone in the upper troposphere from MIPAS-E spectra, Atmos. Chem. Phys. Discuss., 10, 23539-23557, 2010, http://www.atmos-chem-phys-discuss.net/10/23539/2010/.

Nemecek-Marshall, M., MacDonald, R., Franzen, J., Wojciechowski, C., and Fall, R.: Methanol emission from leaves (enzymatic detection of gas-phase methanol and relation of methanol fluxes to stomatal conductance and leaf development), Plant Physiol., 108, 1359-1368, 1995.

Nguyen, H., Takenaka, N., Bandow, H., Maeda, Y., de Oliva, S., Botelho, M., and Tavares, T.: Atmospheric alcohols and aldehydes concentrations measured in Osaka, Japan and in Sao Paulo, Brazil, Atmos. Environ., 35, 3075-3083, 2001.

Palmer, P., Abbot, D., Fu, T., Jacob, D., Chance, K., Kurosu, T., Guenther, A., Wiedinmyer, C., Stanton, J., Pilling, M., et al.: Quantifying the seasonal and interannual variability of North American isoprene emissions using satellite observations of the formaldehyde column, J. Geophys. Res., 111, D12315, doi:10.1029/2005JD006689, 2006.

Paton-Walsh, C., Wilson, S., Jones, N., and Griffith, D.: Measurement of methanol emissions from Australian wildfires by ground-based solar Fourier transform spectroscopy, Geophys. Res. Lett., 35, L08810, doi:10.1029/2006GL027128, 2008.

Paulot, F., Crounse, J. D., Kjaergaard, H. G., Kroll, J. H., Seinfeld, J. H., and Wennberg, P. O.: Isoprene photooxidation: new insights into the production of acids and organic nitrates, Atmos. Chem. Phys., 9, 1479-1501, doi:10.5194/acp-9-1479-2009, 2009.

Perrin, A. and Vander Auwera, J.: An improved database for the $9 \mu \mathrm{m}$ region of the formic acid spectrum, J. Quant. Spectrosc. Ra., 108, 363-370, 2007.

Perrin, A., Vander Auwera, J., and Zelinger, Z.: High-resolution Fourier transform study of the $\nu_{3}$ fundamental band of transformic acid, J. Quant. Spectrosc. Ra., 110, 743-755, 2009.

Phulpin, T., Blumstein, D., Prel, F., Tournier, B., Prunet, P., and Schlüssel, P.: Applications of IASI on MetOp-A: first results and illustration of potential use for meteorology, climate monitoring and atmospheric chemistry, Proc. SPIE, p. 6684, 2007.

Puxbaum, H., Rosenberg, C., Gregori, M., Lanzerstorfer, C., Ober, E., and Winiwarter, W.: Atmospheric concentrations of formic and acetic acid and related compounds in eastern and northern Austria, Atmos. Environ., 22, 2841-2850, 1988.

Rasmussen, R. and Khalil, M.: Isoprene over the Amazon basin, J. Geophys. Res., 93, 1616, doi:10.1029/JD093iD02p01417, 1988.

Razavi, A., Clerbaux, C., Wespes, C., Clarisse, L., Hurtmans, D., Payan, S., Camy-Peyret, C., and Coheur, P. F.: Characterization of methane retrievals from the IASI space-borne sounder, Atmos. Chem. Phys., 9, 7889-7899, doi:10.5194/acp-9-7889-2009, 2009.

Reiner, T., Möhler, O., and Arnold, F.: Measurements of acetone, acetic acid, and formic acid in the northern midlatitude upper troposphere and lower stratosphere, J. Geophys. Res., 104, 13943, doi:10.1029/1999JD900030, 1999.

Remedios, J., Allen, G., Waterfall, A., Oelhaf, H., Kleinert, A., and Moore, D.: Detection of organic compound signatures in infra-red, limb emission spectra observed by the MIPASB2 balloon instrument, Atmos. Chem. Phys., 7, 1599-1613, doi:10.5194/acp-7-1599-2007, 2007.

Rinsland, C., Mahieu, E., Zander, R., Goldman, A., Wood, S., and Chiou, L.: Free tropospheric measurements of formic acid (HCOOH) from infrared ground-based solar absorption spectra: Retrieval approach, evidence for a seasonal cycle, and comparison with model calculations, J. Geophys. Res., 109, D18308, doi:10.1029/2004JD004917, 2004.

Rinsland, C., Dufour, G., Boone, C., Bernath, P., and Chiou, L.: Atmospheric Chemistry Exeriment (ACE) measurements of elevated Southern Hemisphere upper tropospheric $\mathrm{CO}, \mathrm{C}_{2} \mathrm{H}_{6}$, $\mathrm{HCN}$, and $\mathrm{C}_{2} \mathrm{H}_{2}$ mixing ratios from biomass burning emissions and long-range transport, Geophys. Res. Lett., 32, L20803, doi:10.1029/2005GL024214, 2005.

Rinsland, C., Boone, C., Bernath, P., Mahieu, E., Zander, R., Dufour, G., Clerbaux, C., Turquety, S., Chiou, L., Mc-Connell, J., Neary, L., and Kaminski, J. W.: First space-based observations of formic acid ( $\mathrm{HCOOH})$ : Atmospheric Chemistry Experiment austral spring 2004 and 2005 Southern Hemisphere tropical-midlatitude upper tropospheric measurements, Geophys. Res. Lett., 33, L23804, doi:10.1029/2006GL027128, 2006.

Rinsland, C., Dufour, G., Boone, C., Bernath, P., Chiou, L., Coheur, P., Turquety, S., and Clerbaux, C.: Satellite boreal measurements over Alaska and Canada during June-July 2004: Simultaneous measurements of upper tropospheric CO, $\mathrm{C}_{2} \mathrm{H}_{6}, \mathrm{HCN}, \mathrm{CH}_{3} \mathrm{Cl}, \mathrm{CH}_{4}, \mathrm{C}_{2} \mathrm{H}_{2}, \mathrm{CH}_{3} \mathrm{OH}, \mathrm{HCOOH}, \mathrm{OCS}$, and $\mathrm{SF}_{6}$ mixing ratios, Global Biogeochem. Cy., 21, GB3008, doi:10.1029/2006GB002795, 2007.

Rinsland, C., Mahieu, E., Chiou, L., and Herbin, H.: First groundbased infrared solar absorption measurements of free tropospheric methanol $\left(\mathrm{CH}_{3} \mathrm{OH}\right)$ : Multidecade infrared time series from Kitt Peak $\left(31.9^{\circ} \mathrm{N} 111.6^{\circ} \mathrm{W}\right)$ : Trend, seasonal cycle, and comparison with previous measurements, J. Geophys. Res., 114, D04309, doi:10.1029/2008JD011003, 2009.

Rodgers, C. D.: Inverse methods for atmospheric sounding: theory and practise, World Sci., River Edge, NJ, USA, 2000, 2000.

Sanhueza, E. and Andreae, M.: Emission of formic and acetic acids from tropical savanna soils, Geophys. Res. Lett., 18, 1707-1710, 1991.

Sanhueza, E., Figueroa, L., and Santana, M.: Atmospheric formic and acetic acids in Venezuela, Atmos. Environ., 30, 1861-1873, 1996.

Schade, G. and Goldstein, A.: Seasonal measurements of acetone and methanol: Abundances and implications for atmospheric budgets, Global Biogeochem. Cy., 20, GB1011, doi:10.1029/2005GB002566, 2006.

Shim, C., Wang, Y., Choi, Y., Palmer, P., Abbot, D., and Chance, K.: Constraining global isoprene emissions with Global Ozone Monitoring Experiment (GOME) formaldehyde column measurements, J. Geophys. Res., 110, D24301, doi:10.1029/2004JD005629, 2005.

Singh, H., Chen, Y., Tabazadeh, A., Fukui, Y., Bey, I., Yantosca, R., Jacob, D., Arnold, F., Wohlfrom, K., Atlas, E., et al.: Distribution and fate of selected oxygenated organic species in the troposphere and lower stratosphere over the Atlantic, J. Geophys. Res., 105, 3795-3805, 2000.

Singh, H., Salas, L., Chatfield, R., Czech, E., Fried, A., Walega, J., 
Evans, M., Field, B., Jacob, D., Blake, D., Heikes, B., Talbot, R., Sachse, G., Crawford, J., Avery, M., Sandholm, S., and Fuelberg, H.: Analysis of the atmospheric distribution, sources, and sinks of oxygenated volatile organic chemicals based on measurements over the Pacific during TRACE-P, J. Geophys. Res., 109, D15S07, doi:10.1029/2003JD003883, 2004.

Souza, S., Vasconcellos, P., and Carvalho, L.: Low molecular weight carboxylic acids in an urban atmosphere: Winter measurements in Sao Paulo City, Brazil, Atmos. Environ., 33, 25632574, 1999.

Stavrakou, T., Müller, J.-F., De Smedt, I., Van Roozendael, M., van der Werf, G. R., Giglio, L., and Guenther, A.: Global emissions of non-methane hydrocarbons deduced from SCIAMACHY formaldehyde columns through 2003-2006, Atmos. Chem. Phys., 9, 3663-3679, doi:10.5194/acp-7-1599-2007, 2009.

Stavrakou, T., Müller, J.-F., Guenther, A., Razavi, A., Clarisse, L., Clerbaux , C., Coheur, P.-F., Hurtmans, D., Karagulian, F., De Mazière, M., Vigouroux, C., Amelynck, C., Schoon, N., Laffineur, Q., Heinesch, B. and Aubinet, M.: First space-based derivation of the global atmospheric methanol emission fluxes, Atmos. Chem. Phys. Discuss., submitted, 2010.

Talbot, R., Beecher, K., and Harriss, R.: Atmospheric geochemistry of formic and acetic acids at a mid-latitude temperate site, J. Geophys. Res., 93, 1638-1652, 1988.

Talbot, R., Andreae, M., Berresheim, H., Jacob, D., and Beecher, K.: Sources and sinks of formic, acetic, and pyruvic acids over central Amazonia 2. Wet season, J. Geophys. Res., 95, 799-816, 1990.

Tie, X., Guenther, A., and Holland, E.: Biogenic methanol and its impacts on tropospheric oxidants, Geophys. Res. Lett, 30(17), 1881, doi:10.1029/2003GL017167, 2003.

Tsigaridis, K. and Kanakidou, M.: Secondary organic aerosol importance in the future atmosphere, Atmos. Environ., 41, 46824692, 2007.

Turquety, S., Hurtmans, D., Hadji-Lazaro, J., Coheur, P.-F., Clerbaux, C., Josset, D., and Tsamalis, C.: Tracking the emission and transport of pollution from wildfires using the IASI CO retrievals: analysis of of the summer 2007 Greek fires, Atmos. Chem. Phys., 9, 4897-4913, doi:10.5194/acp-9-4897-2009, 2009.

Vander Auwera, J., Didriche, K., Perrin, A., and Keller, F.: Absolute line intensities for formic acid and dissociation constant of the dimer, The J. Chem. Phys., 126, 124311, doi:10.1063/1.2712439, 2007.

Vrekoussis, M., Wittrock, F., Richter, A., and Burrows, J. P.: Temporal and spatial variability of glyoxal as observed from space, Atmos. Chem. Phys., 9, 4485-4504, doi:10.5194/acp-9-44852009, 2009.
Warneke, C., Karl, T., Judmaier, H., Hansel, A., Jordan, A., Lindinger, W., and Crutzen, P.: Acetone, methanol, and other partially oxidized volatile organic emissions from dead plant matter by abiological processes: Significance for atmospheric $\mathrm{HO}_{\mathrm{x}}$ chemistry, Global Biogeochem. Cy., 13, 9-17, 1999.

Wespes, C., Hurtmans, D., Clerbaux, C., Santee, M. L., Martin, R. V., and Coheur, P.-F.: Global distributions of nitric acid from IASI/MetOP measurements, Atmos. Chem. Phys., 9, 7949-7962, doi:10.5194/acp-9-7949-2009, 2009.

Wilber, A., Kratz, D., and Gupta, S.: Surface emissivity maps for use in satellite retrievals of longwave radiation, NASA Tech. Publ., 209362, 35, 1999.

Wittrock, F., Richter, A., Oetjen, H., Burrows, J., Kanakidou, M., Myriokefalitakis, S., Volkamer, R., Beirle, S., Platt, U., and Wagner, T.: Simultaneous global observations of glyoxal and formaldehyde from space, Geophys. Res. Lett., 33, L16804, doi:10.1029/2006GL026310, 2006.

Worden, H., Beer, R., and Rinsland, C.: Airborne infrared spectroscopy of 1994 western wildfires, J. Geophys. Res., 102, 1287 1300, 1997.

Xu, L. H., Lees, R. M., Wang, P., Brown, L. R., Kleiner, I., and Johns, J. W. C.: New assignments, line intensities, and HITRAN database for $\mathrm{CH}_{3} \mathrm{OH}$ at $10 \mu \mathrm{m}$, J. Mol. Spectrosc., 228, 453-470, 2004.

Yokelson, R., Susott, R., Ward, D., Reardon, J., and Griffith, D.: Emissions from smoldering combustion of biomass measured by open-path Fourier transform infrared spectroscopy, J. Geophys. Res., 102(18), 18865-18877, doi:10.1029/97JD00852, 1997.

Yokelson, R., Goode, J., Ward, D., Susott, R., Babbitt, R., Wade, D., Bertschi, I., Griffith, D., and Hao, W.: Emissions of formaldehyde, acetic acid, methanol, and other trace gases from biomass fires in North Carolina measured by airborne Fourier transform infrared spectroscopy, J. Geophys. Res., 104, 30109, doi:10.1029/1999JD900817, 1999.

Yokelson, R., Bertschi, I., Christian, T., Hobbs, P., Ward, D., and Hao, W.: Trace gas measurements in nascent, aged, and cloudprocessed smoke from African savanna fires by airborne Fourier transform infrared spectroscopy (AFTIR), J. Geophys. Res., 108, 8478, doi:10.1029/2002JD002322, 2003.

Zander, R., Duchatelet, P., Mahieu, E., Demoulin, P., Roland, G., Servais, C., Vander Auwera, J., Perrin, A., Rinsland, C., and Crutzen, P.: Formic acid above the Jungfraujoch during 19852007: observed variability, seasonality, but no long-term background evolution, Atmos. Chem. Phys. Discuss., 10, 1477114814, 2010, http://www.atmos-chem-phys-discuss.net/10/14771/2010/. 